\title{
The Great Escape: The Power of Cancer Stem Cells to Evade Programmed Cell Death
}

\author{
Vanessa Castelli $^{1}{ }^{\mathbb{D}}$, Antonio Giordano ${ }^{2,3}$, Elisabetta Benedetti ${ }^{1}{ }^{\mathbb{D}}$, Francesco Giansanti $^{1}{ }^{(\mathbb{D}}$, \\ Massimiliano Quintiliani ${ }^{1}$, Annamaria Cimini ${ }^{1,3, *}$ and Michele d'Angelo ${ }^{1, *}$ (D) \\ 1 Department of Life, Health and Environmental Sciences, University of L'Aquila, 67100 L'Aquila, Italy; \\ vanessa.castelli@univaq.it (V.C.); elisabetta.benedetti@univaq.it (E.B.); francesco.giansanti@univaq.it (F.G.); \\ mquintiliani@unite.it (M.Q.) \\ 2 Department of Medical Biotechnology, University of Siena, 53100 Siena, Italy; antonio.giordano@temple.edu \\ 3 Sbarro Institute for Cancer Research and Molecular Medicine and Center for Biotechnology, \\ Temple University, Philadelphia, PA 19122, USA \\ * Correspondence: annamaria.cimini@univaq.it (A.C.); michele.dangelo@univaq.it (M.d.)
}

Citation: Castelli, V.; Giordano, A.; Benedetti, E.; Giansanti, F.; Quintiliani, M.; Cimini, A.; d'Angelo, M. The Great Escape: The Power of Cancer Stem Cells to Evade Programmed Cell Death. Cancers 2021, 13, 328. https://doi.org/ 10.3390 / cancers 13020328

Received: 31 December 2020 Accepted: 14 January 2021 Published: 17 January 2021

Publisher's Note: MDPI stays neutral with regard to jurisdictional clai$\mathrm{ms}$ in published maps and institutional affiliations.

Copyright: $\odot 2021$ by the authors. Licensee MDPI, Basel, Switzerland. This article is an open access article distributed under the terms and conditions of the Creative Commons Attribution (CC BY) license (https:// creativecommons.org/licenses/by/ $4.0 /)$.
Simple Summary: Several current therapies fail to eradicate tumors due to the ability of cancer stem cells (CSCs) to escape different programmed cell deaths. In fact, apoptosis, autophagy, and necroptosis are deregulated in CSCs. Over the years, it has emerged that CSCs play a key role in tumor formation, progression, and recurrence. Thus, developing CSC-selective and programmed death-inducing therapeutic approaches appears of primary importance. In this review, we focus on signaling pathways involved in CSCs' escape-death ability and the variety of CSC-targeting agents developed in recent years.

Abstract: Cancer is one of the primary causes of death worldwide. Tumour malignancy is related to tumor heterogeneity, which has been suggested to be due to a small subpopulation of tumor cells named cancer stem cells (CSCs). CSCs exert a key role in metastasis development, tumor recurrence, and also epithelial-mesenchymal transition, apoptotic resistance, self-renewal, tumorigenesis, differentiation, and drug resistance. Several current therapies fail to eradicate tumors due to the ability of CSCs to escape different programmed cell deaths. Thus, developing CSC-selective and programmed death-inducing therapeutic approaches appears to be of primary importance. In this review, we discuss the main programmed cell death occurring in cancer and the promising CSC-targeting agents developed in recent years. Even if the reported studies are encouraging, further investigations are necessary to establish a combination of agents able to eradicate CSCs or inhibit their growth and proliferation.

Keywords: cancer stem cells; programmed death; therapeutic approaches; recurrence; metastasis

\section{Introduction}

Cancer is one of the primary causes of death worldwide [1]. Tumor malignancy is related to tumor heterogeneity, which has been suggested to be due to a small subpopulation of tumor cells named cancer stem cells (CSCs) [2]. The first isolation of CSCs by fluorescence-activated cell sorting using CD34 and CD38 (CD34+CD38-) surface marker expression was in acute myeloid leukemia and dates back to 1994 [3]. Since then, CSCs have been isolated from numerous solid tumors, including breast, colon, lung, brain, and prostate tumors using FACS and magnetic cell sorting [4-9]. To date, CSC recognition has been mostly based on surface markers as well as their capability to propagate and selfrenew. Nevertheless, CSC surface markers alone are not a consistent method of detecting these subpopulations, thus leading to some uncertainty and disagreement in the field. This is due to the fact that it is improbable to use a universal specific marker for the detection of these cells. A few functional markers such as the ATP-binding cassette (ABC) transporter 
and aldehyde dehydrogenase (ALDH), live-cell RNA, single-cell DNA detection, and the activation of some crucial signaling pathways have made identification of CSCs easier [10].

To date, numerous methods have been proposed to detect, characterize, and isolate CSCs (also known as tumor-initiating cells). The approaches are marker-based or markerindependent. Both approaches involve the use of FACS and magnetic-activated cell sorting. The marker-based approaches include the antigenic approach for numerous cell surface markers, such as epithelial-specific antigens CD133, CD44, CD24, and CD166. However, this method shows numerous disadvantages since these markers are not solely expressed by CSCs [11]. An example of the marker-independent strategy is represented by side population (SP), which was originally used to enrich hematopoietic stem cells and leukemia stem cells but was afterward widely utilized to enrich CSCs in different solid tumors [12,13]. This approach is based on the capability of stem cells to exclude Hoechst dye 33342 and appear as a side population compared with normal differentiated cells, which take up the dye and appear as the major population. $\mathrm{ABC}$ transporter family proteins are responsible for dye exclusion and the side population phenotypic profile. Additionally, in this case, there is a problem with overlaps [14]. CSCs have been detected in different types of tumor, and specific markers have been used to isolate and characterize them (Table 1).

Table 1. Types of cancer in which CSCs have been detected and the main markers.

\begin{tabular}{crcc}
\hline Types of Cancer & Markers & References \\
\hline Leukemia & CD34, CD38, CD123, TIM3, CD25, CD32, and CD96 & {$[15-17]$} \\
\hline Breast & CD44, CD24, and ALDH1A1 & {$[18-21]$} & {$[22,23]$} \\
\hline Prostate & PSA $^{-/ l o}$, integrin $\alpha 2 \beta 1$, and CD133 & {$[24,25]$} \\
\hline Melanoma & ABCB5, Nanog, Oct3/4, and CD133 & {$[26-29]$} & {$[30]$} \\
\hline Brain & CD90, CD44, and CD15 & {$[31-33]$} \\
\hline Lung & CD44, CD133, and CD90 & {$[34-36]$} \\
\hline Liver & EpCAM, E-cadherin, CD133, CD29, and CK & {$[37,38]$} \\
\hline Pancreas & CD44, CD24 and epidermal surface antigen, CD133, and CXCR4 & {$[39,40]$} \\
\hline Kidney & Nestin, CD133, CD24a, CXCR7, CD44, and Pax2 & \\
\hline Ovary & CD133, CD44, CD117, EpCAM, LGR5, ALDH1/2, LY6A, and CD24 & \\
\hline
\end{tabular}

Like normal pluripotent stem cells, CSCs display the properties of asymmetric division, the quiescent potentials in a dormant state, a role in the epithelial-mesenchymal transition (EMT), apoptotic resistance, self-renewal, tumorigenesis, differentiation, and drug resistance [41]. Furthermore, CSCs exert a key role in metastasis development and in tumor recurrence [42]. CSCs often show the re-expression of embryonic markers comprising Oct4, Sox2, and Nanog and a distinct metabolic profile from terminally differentiated tumor cells; they inhabit specialized hypoxic microenvironments that provide long-term maintenance [43]. CSC target therapies have long been suggested in conjunction with traditional chemotherapeutic procedures to eradicate both differentiated cells and CSCs and avoid forms of recurrence [44].

CSCs show self-renewal and flexible clonogenic properties and help identify precise tumor microenvironments [45]. The communication between CSCs and their tumor niche is firmly related to the characterization of CSCs [46]; based on this, CSCs can maintain the tumor heterogeneity that causes the malignant behaviors of metastasis, invasion, and drug resistance [47]. The impact of the tumor microenvironment on CSC physiology has been demonstrated to be via intrinsic and extrinsic mechanisms. The intrinsic mechanisms comprise DNA demethylation or methylation and gene mutation, while the extrinsic pathway includes the release of numerous growth factors and cytokines by the tumor microenvironment, inducing the initiation of specific signaling pathways [46]. Moreover, different studies have reported that CSCs may be responsible for tumor resistance to traditional therapy (chemo- and radio-resistance). This resistance is increased by the crosstalk between 
CSCs and the tumor microenvironment, which is characterized by enhanced resistance to hypoxia, the activation of the DNA repair system, and the EMT [48,49]. These mechanisms are at the basis of the therapeutic failures often faced in various tumor situations. Thus, both CSCs and the tumor microenvironment represent relevant therapeutic targets. Several current therapies fail to eradicate tumors due to the ability of CSCs to escape different programmed cell deaths (Figure 1); the residual CSCs can survive and promote cancer recurrence. In this review, we will focus on the main programmed cell deaths and the capacity of CSCs to elude them. Moreover, we discuss a variety of CSC-targeting agents developed in recent years. The exposed evidence highlights that a combination of modulators of programmed cell death and standard chemotherapeutic agents may be an efficient anticancer therapeutic approach. This review aims to encourage researchers to develop and investigate approaches based on the modulation of the reported mechanisms.

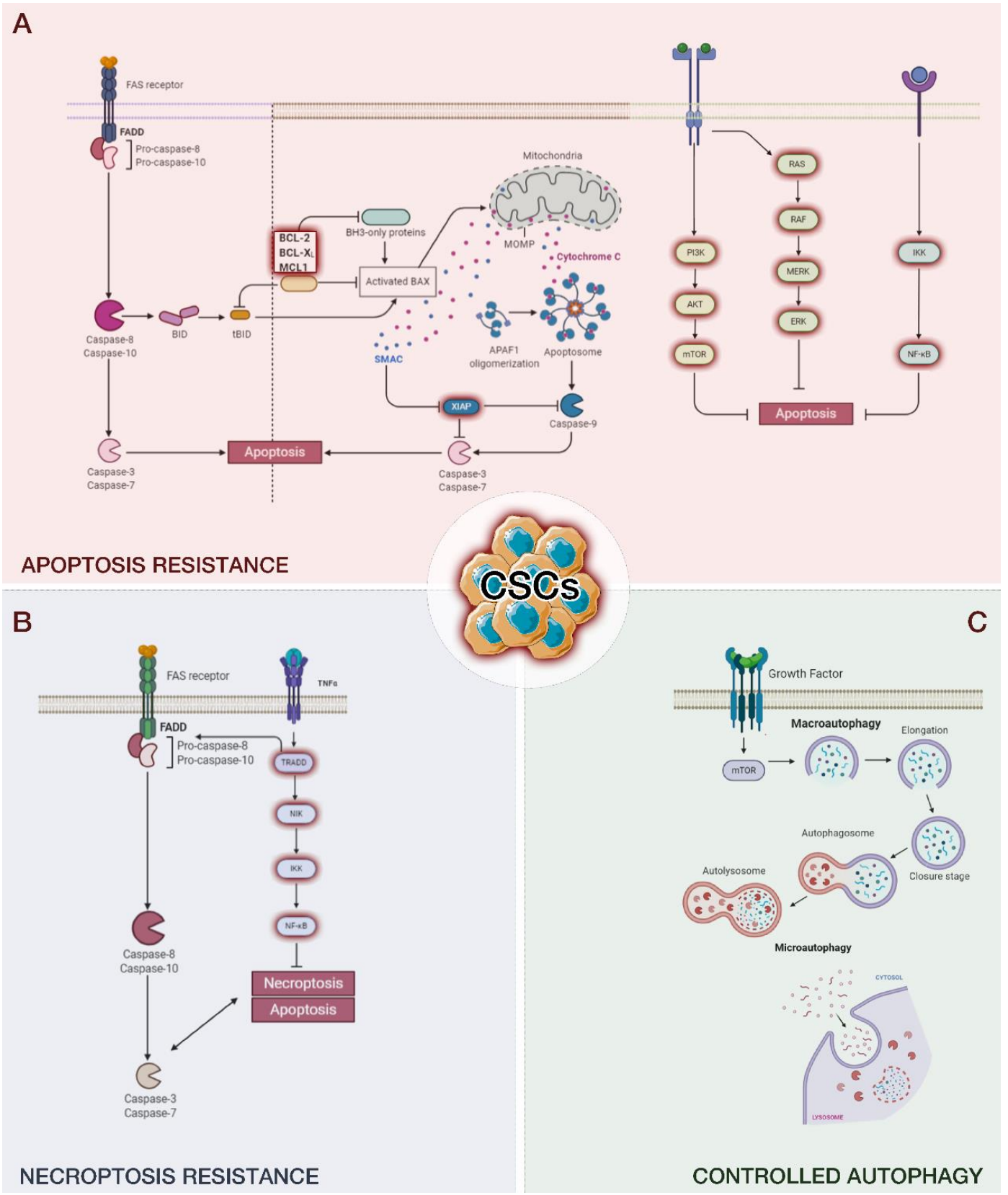

Figure 1. The ability of cancer stem cells (CSCs) to escape different programmed cell deaths, including apoptosis (A), necroptosis (B), and autophagy (C). The remaining CSCs promote cancer recurrence. 


\section{Apoptosis}

Apoptosis is a regulated programmed cell death that plays a key role in tissue development and homeostasis [50]. Apoptosis is, therefore, a highly controlled and regulated process that is necessary for proper functioning and development, not only for tissues but for the whole organism. In fact, the correct balance between survival and death signals is a crucial point - a failure in regulation can lead to the development of tumors [51]. In this context, apoptosis plays an important role in preventing cancer development, such as inducing cells to self-destruct after radiation-induced DNA damage or anticancer drugs [52]. A tumor characteristic linked to specific genetic mutations is precisely the ability to evade the death process and not respond to drugs that induce apoptosis. Many studies have shown that genetic mutations transform normal stem cells into CSCs and enable them to escape apoptosis, which leads to tumor formation (extensively reviewed in [51]). Another way to create apoptosis-resistant CSCs involves dedifferentiation and reprogramming. In particular, numerous lines of evidence have established that CSCs have the potential to transdifferentiate into other lineage cells (pericytes vascular and endothelial cells) for promoting tumor growth and metastasis in some tissue contexts instead of only recruiting stromal cells from neighboring or distant tissues [53].

CSCs inhabit niches that are crucial for their stemness [54]. Non-CSCs in the tumor microenvironment may shield CSCs from chemotherapy [55]. Since CSCs can transdifferentiate into stromal cells in the tumor microenvironment, selectively targeting these CSC-derived cells may disturb the CSC niches and may represent a potential approach for cancer therapy [56]. Nevertheless, to date, there are no specific drugs targeting CSCs. Therefore, inducing the differentiation of CSCs and targeting the CSC-derived stromal cells may help in developing new diagnostic and therapeutic strategies against tumors and may have a clinical advantage when treating cancer.

In particular, CSCs show overexpression of antiapoptotic proteins, including phosphatidylinositol 3-kinase (PI3K)/Akt, NOTCH1, and Wnt/ $\beta$-catenin, and fast repair of the DNA that led to apoptosis resistance [51]. These characteristics of CSCs make them among the main failure factors of anticancer therapies. In fact, the ability of CSCs to evade programmed cell death leads to resistance to various chemotherapeutic agents, such as those used in leukemia, malignant melanoma, brain, head and neck cancers, and breast, colorectal, and pancreas tumors [51,57-59]. Furthermore, resistance to radiotherapy in brain and breast cancers has also been demonstrated. Thus, traditional anticancer treatments can reduce or eliminate cancer cells, but CSCs can survive, leading to the formation of relapses in many types of cancer or metastases by migrating from the primary site of the tumor [59]. In fact, the relative abundance of CSCs is associated with the clinical outcome [59]. We can distinguish two main pathways of apoptosis: intrinsic and extrinsic [60].

\subsection{Intrinsic Pathway}

The intrinsic pathway of apoptosis is based on mitochondria and mitochondrial proteins. DNA damage, oncogenes, growth factor deprivation, microtubule-targeting drugs, DNA-damaging molecules, and $\mathrm{Ca}^{2+}$ surplus can induce this programmed death pathway [61]. P53, following damage to DNA, can induce the intrinsic pathway thanks to the activation of PUMA (P53-upregulated modulator of apoptosis) and Bcl2-associated X protein (BAX), which induce mitochondrial outer membrane permeabilization (MOMP) [62]. MOMP induces the release of cytochrome $c$, the second mitochondria-derived activator of caspase (SMAC) and Omi; this is considered the point of no return of the intrinsic pathway. After their escape from the mitochondrion and their arrival in the cytoplasm, the cytochromes bind to apoptotic protease-activating factor- 1 , dATP, and procaspase- 9 , forming the apoptosome. Then, the apoptosome causes the monomers of procaspase- 9 to unite into dimers and form the active protein (caspase-9), which triggers the executioner caspases-3 and -7. The executioner caspases rapidly act on target proteins, including nuclear lamina, ICAD/DFF45, poly ADP ribose polymerase (PARP), and P21-activated kinase, inducing cell death [63]. 
Cell death triggered by the intrinsic pathway is also enhanced by other mechanisms. Omi (also known as serin protease HtrA2) inhibits caspase inhibitor X-linked inhibitor of apoptosis protein (XIAP), and mitochondria-derived activator of caspase (MAC) is released from the mitochondrion, blocking inhibitor of apoptosis proteins. Furthermore, MOMP can induce cell death in an independent caspase process [64-67]. However, in some tumors, such as breast [68-70], ovary, and skin cancers, it has been shown that CSCs can evade death upon mitochondrial dysfunction [57]. Numerous investigations in colon or breast cancer cells have highlighted a correlation between increased aggressiveness and nonlethal caspase activation [71-73]. In a recent interesting study, Berthenet [74] and collaborators in melanoma cells demonstrated that the resilience of cancer cells to experience complete apoptosis conducts to a more aggressive cancer phenotype. Furthermore, they provide a model to induce and examine the effects of failed apoptosis in physiological settings, such as neuronal function or stemness [74]. Failed apoptosis also seems to influence the emergence of CSCs in breast cancer. In particular, it has been observed that breast cancer cells surviving staurosporine gained metastatic potential in vivo, while some of them developed CSC properties [72].

This point is of high relevance to the scientific community because dissecting the underlying mechanisms of failed apoptosis-driven transcriptional signature (which increases the aggressiveness of a tumor) may improve the targeting of metastatic processes.

\subsection{Extrinsic Pathway}

Extracellular signals can induce apoptosis via the extrinsic pathway. The main cell death signals are Fas ligand (Fas-L), TNF-related apoptosis-inducing ligand (TRAIL), and tumor necrosis factor (TNF), also called death ligands [75]. These signals bind to tumor necrosis factor (TNF) family death receptors, inducing adaptor protein recruitment that includes the Fas-associated death domain (FADD) and the TNF-receptor-associated death domain (TRADD) [75]. The adaptor protein binds initiator procaspases- 8 and -10 , forming the death-inducing signaling complex (DISC) and converting procaspases- 8 and -10 to their active form, which further activates effector caspases-3, -6, and -7 [76]. These effector caspases lead to cell death by the cleavage of proteins and the cytoskeleton. The extrinsic and intrinsic pathways meet after the activation of caspase-8. DISC is a multiprotein complex composed of members of the death receptor family of apoptosis-inducing cellular receptors [77-79]. TNF binds to TNFR1 and TNFR2. However, only TNFR1 contains a death domain and is part of the death receptor subfamily [80,81]; the interaction between TNF and TNFR1 leads to the formation of the TNFR1 signaling complex (TNFR1-SC).

In the extrinsic pathway, the activation of caspase-8 induces $\mathrm{BH} 3$ interacting-domain death agonist (BID) activation, a BH3-only protein [60]. BID, in turn, oligomerizes BAX and BCL2 homologous antagonist/killer (BAK), and the intrinsic apoptotic pathway proceeds. Both pathways will keep on propagating via their typical course, supporting apoptosis (Figure 1A) [60].

\subsection{Mechanisms of CSCs to Evade Apoptosis}

Apoptosis, a natural mechanism of cell death, can be used as an effective tool in anticancer therapy $[61,82,83]$. In fact, there are several anticancer drugs that target apoptosis in both intrinsic and extrinsic ways. This strategy represents the most effective nonsurgical treatments [51]. However, CSCs show an innate resistance to apoptosis through several mechanisms, including multidrug resistance transporters. ABC family overexpression in CSCs is involved in multidrug resistance. The ABC family is characterized by 49 members, including multidrug resistance protein 1 (MRP1, ABCC1), breast cancer resistance protein (BCRP, ABCG2) [84-87], MRP5/ABCC5 [87], and P-glycoprotein (P-gp, MDR1, ABCB1) [88]. It has been shown that CSCs are upregulated in numerous cancers, including colon, glioblastoma, prostate, and pancreas, contributing to drug resistance [89-93]. In addition to the ability to transport the drug outside the cell, reducing the amount needed to trigger cell death, it has been proposed that these transporters contribute to tumorige- 
nesis [94,95]. Given the role of $\mathrm{ABC}$ in drug resistance, several therapies have been tried over the years; however, the targeting of $\mathrm{ABC}$ transporters in cancer patients has been unsuccessful [84].

Another pathway involved in the evading mechanism from CSCs is PI3K/AKT/mTOR signaling. This pathway is fundamental for proliferation, metabolism, invasion, and survival and, therefore, for tumor development and the maintenance of CSCs [96]. $\mathrm{PI} 3 \mathrm{~K} / \mathrm{AKT} / \mathrm{mTOR}$ inhibitors have been developed and tested in recent years, including salinomycin, metformin, silibinin E1201, rottlerin, and torin [97]. Yang and collaborators demonstrated that resistance to TMZ can be increased in GBM by using metformin; metformin in combination with sorafenib as an RAF inhibitor also substantially diminished CSC oxidative stress and efflux pump activity and eradicated these tumor cells [98]. Moreover, another inhibitor of the PI3K/AKT/mTOR pathway, BFZ-235, induced a stemness reduction of colon CSCs [99].

Furthermore, an alteration of the ratio between apoptotic and antiapoptotic proteins is essential in the development of various tumors and contributes to the maintenance of CSCs. However, their contribution to drug resistance has not yet been well characterized. In CSCs, a high expression in BCL2 family proteins, which consist of proapoptotic proteins Bax, Bak, Bid, Bim, Bik, Noxa, and Puma and antiapoptotic molecules Bcl-2, Bcl-XL, and Mcl-1, was observed $[100,101]$. The altered relationship between pro- and anti-apoptotic proteins is related to the resistance of CSCs to apoptosis and anticancer therapies. In addition, in CSCs, a large increase in the expression of nuclear factor erythroid 2-related factor 2 (Nrf2) can be observed [102]. Nrf2 is the redox-sensing transcription factor that stimulates the expression of ABCG2, Bcl-2, and Bmi-1, a member of polycomb repressor complex (PRC1) genes, promoting CSC survival [103]. Based on this evidence, approaches targeting these antiapoptotic proteins are relevant in counteracting the resistance to apoptosis from CSCs.

TRADD is involved in several receptor signaling pathways and has a key role in different biological processes, including cell survival and apoptosis in different cellular contexts [104]. Extracellular TNF can activate TNFR1, which, in turn, leads intracellular proteins to activate numerous signaling pathways, such as mitogen-activated protein (MAP) kinase pathways and nuclear factor $\mathrm{\kappa B}$ (NF- $\mathrm{kB}$ ) [105]. In CSCs, TRADD has an essential role in NF- $\mathrm{KB}$ activation, in which the exposed nuclear localization signal enters the nucleus and binds to specific sequences of DNA for prosurvival signaling $[106,107]$. $\mathrm{NF}-\mathrm{KB}$ is the transcription factor that stimulates the expression of a variety of inflammatory cytokines and apoptosis inhibitory proteins $[108,109]$. A high expression of TRADD, enough to activate NF- $\mathrm{KB}$, was observed in glioblastoma [110]. Furthermore, a reduction in cell viability was observed by reducing the activation of NF- $\mathrm{KB}$ through the silencing of TRADD, confirming the role of TRADD in the survival of CSCs [110]. The use of NF- $k B$ inhibitors, such as parthenolide, pyrrolidinedithiocarbamate, and diethyldithiocarbamate, showed an induction of apoptosis in human prostate and breast cancer CSCs but not in normal stem cells, indicating a potential use of this inhibitor in cancer therapy [111,112].

The inhibitor of apoptosis (IAP) family proteins directly or indirectly inhibit the apoptotic cascade and play an essential role in the survival of tumor cells, especially in CSCs [113]. Furthermore, some IAPs are involved in the activation of the NF- $k B$ pathway and positively regulate cell survival. The IAP family proteins are composed of numerous proteins involving cIAP2, survivin, IAP1, ML-IAP, XIAP, NAIP, and ILP-2 [114]. IAPs constrain the activity of caspases-3, -7 , and -9 , implicated in the evasion of tumor cells from apoptotic death [115]. In human cancers, the expression or function of IAP proteins is deregulated, and the expression levels of IAP proteins and their antagonists have been associated with clinical parameters and cancer prognosis [116,117]. Among the IAP family members, XIAP may have the strongest antiapoptotic activities compared to other IAPs, upon a specific stimulus (i.e., depletion of cIAP1/2) [118-121]; it prevents caspase-9 activation, binding to active caspases-3 and -7 [122]. It has been reported that XIAP has the function of directly inhibiting caspase, and structural and biochemical studies have accurately mapped the elements of XIAP that are necessary for caspase inhibition, which, 
interestingly, are not conserved among IAPs $[123,124]$. Indeed, it has been shown that $\mathrm{XIAP}$ is probably the only real caspase inhibitor, implying that the other family members have never achieved the capability to prevent caspase activity directly $[123,125]$.

XIAP proteins play a key role in regulating apoptosis in CSCs and are expressed at higher levels in glioblastoma and nasopharyngeal carcinoma stem cells [126]. IAP inhibitors have been successfully tested in glioblastoma, ovarian cancer, and colon and nasopharyngeal carcinoma [126]. In a radioresistant glioblastoma cell line, XIAP inhibitors favored apoptosis induced by gamma-irradiation [127].

FLICE-inhibitory protein (c-FLIP) is the main antiapoptotic protein that cooperates with FADD, caspases-8 or -10, and DR5 to inhibit the formation of DISC and the resultant activation of the caspase cascade. Responsible for resistance to chemotherapy-induced apoptosis, C-FLIP is overexpressed in several cancers, such as breast cancer, glioblastoma, and leukemia; however, its levels in CSCs are much higher than in normal cancer cells [128,129], inducing resistance to TRAIL-induced apoptosis. In fact, cFLIP silencing makes CSCs sensitive to TRAIL-induced apoptosis, indicating the role of cFLIP in death resistance $[128,129]$.

The use of specific drugs against c-FLIP isoforms can improve the effectiveness of chemotherapy treatments. Sorafenib, a broad-spectrum kinase inhibitor targeting the RAF-MEK-ERK pathway, enhanced sensitization to TRAIL- or FAS-mediated apoptosis by downregulation of cFLIP in endometrial carcinoma cell lines that are resistant to TRAIL or FAS [130]. Piggott et al. [131] showed that the use of a cFLIP inhibitor, in combination with TRAIL treatment, caused a reduction in tumor growth and metastasis formation in an in-vivo model of breast cancer. The treatment inhibited CSC self-renewal but did not induce the death of healthy mammary cells [131].

It has been demonstrated that CSCs are resistant to DNA-damaging therapies by controlling the cell cycle, improving DNA repair capacity and the scavenging of reactive oxygen species [132-135]. Interestingly, Bartucci et al. [136] reported that the co-administration of Chk1 inhibitor AZD7762 and chemotherapy inhibited nonsmall-cell lung (NSCL) CSC growth in mouse xenografts in a p53-independent manner. Additionally, targeting CHK1 and PARP1 may be an efficient anti-CSC approach [132].

\section{Ferroptosis}

CSCs can be eliminated by ferroptosis, which is a nonapoptotic-regulated mechanism of cell death [137]. Ferroptosis is a nonapoptotic, regulated cell death characterized by abnormal metabolism of cellular lipid oxides catalyzed by iron ions or iron-containing enzymes. During ferroptosis, numerous inducers eliminate the cell redox balance and generate a large number of lipid peroxidation products, ultimately causing cell death [138]. In contrast to normal cancer cells, in CSCs, enhanced iron content has been found. Consistently, iron chelation may reduce their stemness, while iron supplements may counteract this effect, exerting protective effects in CSCs $[139,140]$. Accordingly, iron deficiency impeded cell proliferation in mouse-induced pluripotent cells and inhibited the expression of stemness markers [141]. These results suggest that iron may exert a dual function in CSCs. Different investigations have reported that the levels of the iron exporter ferroportin as well as storage protein ferritin are reduced in ovarian CSCs and cholangiocarcinoma CSCs $[139,142]$. Moreover, reduced expression of ferritin and high transferrin receptor levels were found in cholangiocarcinoma cells growing in monolayers, while higher levels of ferritin and low expression of transferrin receptor were reported in the same cell lines growing in spheroids [142], suggesting that iron is crucial for spheroid formation. The knock-down of ferritin counteracted glioblastoma CSC growth and reduced a stem-like phenotype in breast cancer $[143,144]$. These investigations demonstrate that CSCs are iron-rich and iron-dependent. Notably, ovarian CSCs showed greater sensitivity to ferroptosis than nontumorigenic ovarian stem cells [142]. As mentioned above, ferritin exerts a dual role in CSCs: in slow-growing CSCs, iron is not essential for proliferation and may be stored as ferritin, thus avoiding the generation of lipid peroxidation and explaining 
the resistance of cholangiocarcinoma cells with high ferritin content to erastin. Similarly, if ferritin degradation starts, ferritin may also represent a source of iron, thus causing ferroptosis [141]. Recently, Müller et al. reported a fascinating role for iron in inducing the expression of CSC marker CD44 [145]. They also show a new mechanism of iron entry in cells under the mesenchymal state. Similar to transferrin receptor 1, CD44 may also perform as an alternative route for iron entry when the transferrin receptor is downregulated due to higher intracellular levels of iron [145], confirming that CSCs are dependent on high intracellular iron levels. Indeed, iron chelation was linked to the downregulation of stemness genes, CSC surface markers including CD133, CD44, and CD24, as well as EMTinducing transcription factors [141]. Overall, the induction of ferroptosis is an attractive strategy to eradicate tumors due to its ability to selectively target aggressive CSCs.

\section{Necroptosis}

Necroptosis exerts a crucial role in the regulation of cancer biology, comprising cancer subtypes, cancer immunity, cancer metastasis, and oncogenesis $[146,147]$. Necroptosis is a type of regulated necrosis mediated by death receptors $[148,149]$. The key mediators of the necroptotic pathway, alone or combined with other programmed cell deaths, have been indicated to encourage cancer progression and metastasis [150-152]. Contrarily, necroptosis also apparently operates as a "fail-safe", protecting against tumor progression when apoptosis is altered [153,154]. Based on its pivotal role in cancer biology, necroptosis has appeared as a new target for cancer treatment; an increasing number of therapeutic agents have shown potential in counteracting tumor growth and recurrence by stimulating or controlling necroptosis [155]. Necroptosis is determined by both the induction of mitochondrial uncoupling proteins and the blocking of oxidative phosphorylation in CSCs [156]. Necroptosis is also related to the ALDH family, which may represent a potential therapeutic target for CSCs (Figure 1B) [157].

\section{Autophagy}

Autophagy is a highly conserved catabolic process involved in organelle turnover, protein degradation, and nonselective breakdown of cytoplasmic components. There are three primary kinds of autophagy in mammalian cells: microautophagy, chaperonemediated autophagy (CMA), and macroautophagy [158]. All types of autophagy finish in the delivery of cargo to the lysosome for degradation and recycling, but they are morphologically different. Microautophagy uses lysosomal membrane invaginations to capture cargo. Instead, during CMA, chaperones are used to identify cargo proteins without using membranous structure; the proteins with a pentapeptide motif are unfolded and translocated directly across the lysosomal membrane [159].

In contrast to microautophagy and CMA, macroautophagy includes the elimination of cargo away from the lysosome. It is based on the formation of autophagosomes and double-membrane vesicles and happens at the basal level in all cells. It can be caused by several signals and/or cellular stressors, including hypoxia, radiation, deficiencies in nutrients and energy, damage of mitochondrial/DNA, and endoplasmic reticulum (ER) stress $[160,161]$. The autophagic process can be divided into five steps: initiation, elongation and autophagosome formation, fusion, and autolysosome formation and degradation. Autophagosome production and autophagy are regulated by over 20 core autophagy genes (ATGs) that are highly conserved [160].

Autophagosome formation (initiation) is required in the mammalian cell Unc51-like kinase 1 (ULK1) complex formed by ULK, Atg13, Atg101, and FIP200 [162-165]. The target of rapamycin (mTOR) complex 1 is the main negative regulator of autophagy, inhibiting the activation of the ULK1 complex. Autophagosome elongation and maturation require two ubiquitin-like conjugation systems, including the microtubule-associated protein 1light chain 3 (LC3) system and the Atg12 system (associated with Atg5 by Atg10 and Atg7) [166]. Autophagic membrane elongation is promoted by the Atg12-Atg5 complex interacting with Atg16L. Concomitantly, the LC3 (LC3-I) cytosolic form is conju- 
gated to phosphatidylethanolamine by Atg7 and Atg3, forming the insoluble form LC3phosphatidylethanolamine conjugate (LC3-II), which is inserted into the autophagosomal membrane. Finally, the autophagosome, including organelles and cargo proteins, is fused with a lysosome to form an autolysosome, which degrades its content into fatty acids, amino acids, and nucleotides (Figure 1C) [167].

Autophagy is a necessary component to maintain pluripotency in response to various stimuli. Pluripotency is an important characteristic of CSCs, namely, to self-renew and maintain the undifferentiated state [168]. In fact, it has been observed that in several CSCs such as in breast [169,170], pancreatic, liver [171], osteosarcoma [172], ovarian [173], and glioblastoma [174], a high autophagic flow is maintained. Furthermore, it has been proposed that autophagy and hypoxia are essential for the maintenance of the stem cell niche. Indeed, Zhu et al. demonstrated that autophagy is HIF- $1 \alpha$-dependent, and it is important for keeping the equilibrium between pancreatic CSCs and normal cancer cells [175]. Thus, autophagy is an adaptive mechanism necessary for CSC maintenance. The cargo of the autophagosome, including organelles and proteins, is finally degraded, fusing with a lysosome and generating the autophagolysosome. In this step, clinically available therapeutic approaches, comprising chloroquine (CQ) and hydroxychloroquine, impede autophagy, reducing autophagosome and lysosome fusion [160]. Other drugs are in development to target this stage, including D1661, which is an inhibitor of both mTOR and autophagy.

\subsection{Mechanisms of CSCs to Evade Autophagy}

One of the crucial mechanisms that have been firmly correlated with CSC survival, pluripotency, and aggressiveness is autophagy. In fact, autophagy and autophagy proteins are upregulated in breast CSCs $[169,176]$ with respect to adherent cells. Successively, autophagy has been highlighted in numerous kinds of CSCs, not only breast $[169,170]$ but also pancreatic, liver [171], osteosarcoma [172], ovarian [173], and glioblastoma [174] cancer stem cells, in which its failure negatively influences the expression of staminal markers and, thus, the ability of self-renewal. In hematological cancers, autophagy can act as a tumor suppressor and in chemoresistance.

Recently, researchers have focused on dissecting the underlying mechanisms of autophagy-dependent CSC maintenance, and various pathways have been identified. For instance, Yeo and collaborators [177] showed that autophagy performs via EGFR/Stat3 and $\mathrm{Tgf} \beta /$ Smad signaling in two breast cancer stem-like cells (ALDH ${ }^{+}$and $\mathrm{CD} 29 \mathrm{hiCD61}{ }^{+}$, respectively). The authors demonstrated reduced phosphorylation of EGFR depleting FIP200, which, in turn, led to reduced STAT3 activation and, consequently, altered ALDH ${ }^{+}$breast CSCs tumorigenicity. Autophagy inhibition induces reduced TFG $\beta 2$ and TGF $\beta 3$ expression, causing a defect in Smad signaling, which is crucial for the CD29hiCD61+CSC phenotype. Furthermore, in the triple-negative breast CSCs, it has been found that by inhibiting autophagy, the secretion of IL-6 was reduced, probably via the STAT3/JAK2 pathway [178]. The secretion of this cytokine is important for CSC survival [179] and necessary to induce the $\mathrm{CD} 44^{+} / \mathrm{CD} 24$ low phenotype in breast cancer cell lines, thus confirming that the IL-6-JAK2-STAT3 pathway may have a key role in the conversion of non-CSCs into CSCs.

It has been suggested that the role of FOXO proteins in autophagy and, in particular, the correlation among FOXO, autophagy, and cancer is emerging (extensively reviewed in [180-182]). In particular, FOXO proteins controlling autophagy regulate cancer growth and metastasis [180-182]. In other investigations, a key role for FOXOs in controlling the fate of CSCs has been indicated [183]. FOXO-dependent regulation of transcription is essential to maintain the homeostasis of stem cells in both embryos and adults [184]; however, the role of FOXO in affecting CSC functions needs to be clarified. The knockdown of FOXO3 led to sustained CSC self-renewal in glioblastoma, prostate, liver, and colorectal cancers and female cancers [185-188]; in contrast, leukemia-initiating cells require FOXO3 for stem cell survival $[189,190]$. However, further investigations are required to comprehend how FOXO-dependent regulation of stemness and autophagy mechanisms 
are interrelated in tumorigenesis. Interestingly, a correlation between autophagy, stemness markers, and $\mathrm{NAD}^{+}$biosynthesis has been reported. Sharif and his group revealed that altering basal autophagy by inhibitors or activators, the pluripotency of teratocarcinoma CSCs was strongly reduced, inducing a state of differentiation or/and senescence [191].

Another research group studying ovarian CSCs has reported a correlation between autophagy and stemness [173]. In particular, Forkhead Box A2 (FOXA2) is overexpressed in ovarian CSCs and controlled by autophagy; indeed, the inhibition of autophagy by pharmacological and genetics methods led to FOXA2 reduction and, in turn, loss of self-renewal capability. Finally, other studies suggested a role for autophagy in controlling chromosome stability; thus, CSCs may activate autophagy to avoid additional DNA damage and, thus, preserve their maintenance [192].

\subsection{Mitophagy}

As mentioned above, autophagy performs a dual role in cancer as tumor suppressor and promoter. Indeed, depending on the context, it may positively or negatively influence tumor growth and invasion. CSCs are usually characterized by a deregulation of pathway autophagy/mitophagy [193]. The modulation of this pathway controls CSC generation, differentiation, plasticity, migration/invasion, and immune and drug resistance. Mitophagy is crucial in the control of normal tissue stem cell homeostasis. Mitophagy controls mitochondria functionality and cellular metabolism [168]. For instance, removing altered mitochondria (the main source of ROS) by mitophagy inhibits senescence and regulates ROS-induced genome injury [194]. Avoiding ROS-induced injuries is essential for the preservation of stemness. A crucial role for mitophagy was reported during the glycolytic switch necessary for mouse neurogenesis [195]. The turnover of mitochondria through mitophagy supports the maintenance of stemness by limiting the capacity of the stem cells for oxidative phosphorylation, increasing the glycolytic activity for energy requests. Inhibiting the mitophagy process, CD44 expression was reduced and the translocation of p53 to the nucleus was supported, where it antagonized the expression of stemness markers [168].

\section{CSC-Targeting Therapeutic Approaches}

As mentioned above, several current therapies fail to eradicate tumors due to the ability of CSCs to escape different programmed cell deaths. Thus, developing CSC-targeting therapeutic approaches appears of primary importance. In the following paragraphs, we report encouraging studies of CSC-targeting that use both natural and synthetic compounds (Table 2).

Table 2. CSC-targeting therapeutic approaches.

\begin{tabular}{|c|c|c|c|}
\hline Compound & Origin & Target/Effects & References \\
\hline 20(S)-ginsenoside $\operatorname{Rg} 3$ & Panax ginseng & Caspases and P53 & {$[196,197]$} \\
\hline Ginsenoside Rb1 & Panax ginseng & $\begin{array}{c}\text { Wnt } / \beta \text {-catenin } \\
\text { Reduces stemness markers }\end{array}$ & [198] \\
\hline Epigallocatechin-3-gallate & Green tea & $\begin{array}{c}\text { Wnt } / \beta \text {-catenin } \\
\text { Inhibits ABC transporter } \\
\text { Reduces stemness markers }\end{array}$ & {$[199,200]$} \\
\hline Resveratrol & Cocoa, grapes, peanuts, berries & $\begin{array}{c}\text { Wnt } / \beta \text {-catenin } \\
\text { Induction of autophagy }\end{array}$ & [201-203] \\
\hline Broussoflavonol B & Broussonetia papyrifera tree & Inhibits growth & [204] \\
\hline Curcumin & Curcuma longa & $\begin{array}{c}\mathrm{ABCG} 2 \\
\text { Increases radio- and chemo-sensitivity of CSCs }\end{array}$ & {$[205,206]$} \\
\hline Morusin & Ramulus mori & $\begin{array}{c}\text { Increases caspase- } 3 \text { and BaxDecreases Bcl-2 and } \\
\text { NF- } \mathrm{kB} / \mathrm{p} 65 \\
\text { Inhibits stemness markers }\end{array}$ & {$[207,208]$} \\
\hline
\end{tabular}


Table 2. Cont.

\begin{tabular}{|c|c|c|c|}
\hline Compound & Origin & Target/Effects & References \\
\hline Diallyl trisulfide & Allium sativum & $\begin{array}{c}\text { Wnt } / \beta \text {-catenin } \\
\text { Inhibits stemness markers }\end{array}$ & {$[209,210]$} \\
\hline IMD-0354 & Synthetic & IKKB and NF- $\kappa B$ & [211] \\
\hline LDE225 & Synthetic & Bmi-1 & [212] \\
\hline NV-128 & Synthetic & MAP/ERK, AMPK $\alpha 1$, and mTOR & [213] \\
\hline Disulfiram & Synthetic & $\begin{array}{l}\text { P-gp, NF-kB, ALDH, p38, and cJun } \\
\text { Inhibits stemness markers } \\
\text { Inhibits ubiquitin-proteasome pathway }\end{array}$ & [214-219] \\
\hline PF-03084014 & Synthetic & Survivin, MCL1 & [220] \\
\hline Sorafenib and FH535 & Synthetic & Survivin & {$[130,221]$} \\
\hline STX-0119 & Synthetic & STAT3, survivin, and c-Myc & [222] \\
\hline 4 diethylaminobenzaldehyde & Synthetic & Bcl-2 and Bax & [223] \\
\hline All-trans retinoic acid & Synthetic & ALDH1/FoxM1/Notch1 & {$[224,225]$} \\
\hline Chloroquine & Synthetic & Autophagy (Hedgehog pathway) & [226] \\
\hline PTC-209 & Synthetic & BMI-1 & [227] \\
\hline $\begin{array}{l}\mathrm{Ni}(\mathrm{II}) \text { dithiocarbamate } \\
\text { phenanthroline }\end{array}$ & Synthetic & Necroptosis & [228] \\
\hline Os(II) bathophenanthroline & Synthetic & Necroptosis & [229] \\
\hline $673 \mathrm{~A}$ & & Necroptosis, ALDH1 & [157] \\
\hline
\end{tabular}

Abbreviations: ABCG2, ATP-binding cassette transporter G2; IKKB, inhibitor of nuclear factor kappa-B kinase; NF-Kb, nuclear factor kappa-light-chain-enhancer of activated B-cells; P-gp, P-glycoprotein; Bcl-2, B-cell lymphoma 2; Bax, B-Cell lymphoma-associated X; MCL-1, myeloid cell leukemia 1; STAT3, signal transducer and activator of transcription 3; ALDH, aldehyde dehydrogenase.

\subsection{Natural Compounds}

Different nutraceuticals are efficient as adjuvant agents for cancer therapy in in-vivo and in-vitro studies [230-233]. A diet abundant in vegetables and fruits is related to cancer risk reduction; however, the mechanisms are still unclear. In particular, sera of transgenic adult mice with a diet rich in soy isoflavone genistein or blueberry polyphenol showed an altered population of stem-like/progenitor cells [234]. In addition, these natural compounds were able to reduce the spheroid formation of breast CSCs [234,235]. 20(S)-ginsenoside Rg3, one of the major components extracted from Panax ginseng, has been shown to have anticancer effects in colon CSCs and induce apoptosis by controlling numerous signaling pathways, including caspases-9 and -3 and P53 [196]. Ginsenoside $\mathrm{Rb} 1$ and its metabolite compound $\mathrm{K}$ inhibited ovarian CSC self-renewal and exposed the CSCs to high doses of chemotherapeutics. The effect of ginsenoside Rb1 on CSCs is related to the inhibition of the Wnt/ $\beta$-catenin signaling pathway by reducing $\beta$-catenin/T-cell factor-dependent transcription and the expression of its target genes (ATP-binding cassette G2 and P-gp) [198]. More recently, ginsenoside Rg3 has been demonstrated to inhibit the growth and stemness of colorectal CSCs both in vivo and in vitro [197].

Notably, epigallocatechin-3-gallate (EGCG), the main component of green tea, reduced lung CSC spheroid size, decreased stemness markers, inhibited proliferation, and stimulated apoptosis. The mechanism is mainly ascribed to the alteration of the Wnt/ $\beta$ catenin pathway [199]. EGCG also suppressed the self-renewal ability of neck and head CSCs, reducing the expression of stemness markers and controlling spheroid formation. Furthermore, EGCG enhanced cisplatin-induced chemosensitivity by inhibiting ABC transporter genes and reducing tumor growth, and it activated apoptosis in xenograft models. The authors have ascribed the main mechanism of the anti-CSC activity of EGCG to the suppression of the Notch pathway [200]. 
Resveratrol is a polyphenol widely used in the traditional Mediterranean diet, which has shown different positive effects [236]. Resveratrol inhibited the Wnt/ $\beta$-catenin signaling pathway in mammospheres in vitro and in vivo and, thus, induced autophagy [201]. Moreover, this polyphenol reduced glioma CSC proliferation and motility by controlling Wnt signaling and EMT activators in glioblastoma multiforme lines [202]. Furthermore, the efficacy of resveratrol mixed with grape seed extract was studied in isolated human colon CSCs in vitro and in a mouse model of colon carcinogenesis; interestingly, this combination suppressed Wnt/ $\beta$-catenin and led to the mitochondrial-mediated apoptosis of CSCs [203]. Broussoflavonol B, a chemical extracted from the Broussonetia papyrifera tree, reduced estrogen receptor (ER)- $\alpha 36$ expression and counteracted ER-negative breast cancer stem-like cell growth, inducing apoptosis [204]. Curcumin, extracted from turmeric, induced CD133+ rectal CSC apoptosis and significantly increased radiosensitivity of rectal CSCs [205]. Curcumin also sensitized breast CSCs to chemotherapy, reducing ABCG2 expression [206].

Furthermore, the flavonoid morusin stimulates apoptosis of cervical CSCs, increasing caspase-3 and Bax in a dose-dependent manner and reducing NF-kB/p65 and Bcl-2 [207]. In addition, morusin was able to constrain human glioblastoma CSC growth in vitro and in vivo, inhibiting stemness markers and adipocyte differentiation and inducing apoptotic death [208]. Upon morusin treatment, CSCs showed increased activity of Bax and caspase-3 in parallel with a decreased activity of Bcl-2 [208].

Diallyl trisulfide (DATS), a garlic-derived organosulfur, showed anticancer activities. Indeed, DATS decreased spheroid size, inhibited proliferation, diminished CSC markers, and triggered apoptosis by inhibiting the Wnt/ $\beta$-catenin pathway and its target genes in colorectal CSCs [209]. Comparably, DATS reduced viability and proliferation, diminished CSC marker expression, and stimulated apoptosis in human breast CSCs by inhibiting the Wnt/ $\beta$-catenin pathway [210].

\subsection{Synthetic Inhibitors}

IMD-0354, an inhibitor of IKKB, modulating IKKB and NF-KB, leads to breast CSC apoptosis [211]. LDE225 (also named Erismodegib or NVP-LDE-225) is a new specific Hedgehog signaling pathway inhibitor and Smoothened antagonist. LDE225 reduces EMT and human prostate CSC growth and spheroid formation in NOD/SCID IL2R $\gamma$ null mice by controlling pro- and antiapoptotic proteins [212].

$\mathrm{NV}-128$ is a synthetic flavonoid derivative that targets mitochondria in CD44 ${ }^{+} / \mathrm{MyD}^{+} 8^{+}$ ovarian CSCs and stimulates apoptosis by supporting cellular cell starvation, which, in turn, triggers two independent pathways: the mitochondrial MAP/ERK pathway, inducing the loss of mitochondrial membrane potential, and the AMPK $\alpha 1$ pathway, inducing mTOR suppression [213].

Disulfiram (DS) is an orally bioavailable ALDH inhibitor that is a thiocarbamate alcoholism drug [214]. It has been reported that DS inhibits the P-gp extrusion pump, blocks NF- $k B$, sensitizes to chemotherapy, decreases angiogenesis, and reduces tumor growth in mice [215]. DS is able to inhibit both ALDH2 and ALDH1 isozymes, which are upregulated in CSCs, suggesting the potential use of DS as an antineoplastic drug [237]. Numerous papers have reported DS anti-cancer effects in different tumors (widely reviewed in [216,217]). The antineoplastic effects of DS are mainly due to the induction of high intracellular ROS levels, thus leading the CSCs towards apoptosis [218]. It has been demonstrated that a DS/copper complex can target ALDH1A1 and reduce tumor relapses that are mainly led by ALDH-high CSCs [238]. In ovarian cancers, DS showed cytotoxic effects similar to chemotherapeutics (i.e., cisplatin, paclitaxel) and also showed a target effect on cancer cells without affecting normal cells [239]. The cytotoxic effect of DS is mainly due to programmed cell death activation; an additive impact in combination with chemotherapy was detected [240]. For instance, DS used in combination with chemotherapeutic 5-fluorouracil (5-FU) showed an increased apoptotic effect on human colorectal cancer cell lines (DLD-1 and RKO (WT) cells) and increased the cytotoxicity of 5-FU. DS was also able to reduce 
5-FU chemoresistance in a chemoresistant cell line H630(5-FU) [215]. In vitro treatment with DS/copper substantially reduced the expression of stem cell markers (Sox2, Oct-4, and Nanog) and lowered the ability of nonsmall cell lung cancer (NSCLC) stem cells for proliferation, invasion, and self-renewal. In NOD/SCID xenograft models of NCI-H1299 cells, DS/copper was administered, and, interestingly, it removed ALDH-positive cells, decreased tumor growth, and abolished tumor recurrence [241].

Liu and collaborators analyzed the cytotoxic effect of DS/copper and DS and gemcitabine on GBM stem-like cells. DS/copper boosts the cytotoxicity of gemcitabine. Combination index-isobologram analyses have suggested a synergistic effect between DS/copper and gemcitabine. The authors showed that the cytotoxicity effects of the combined drugs led to increased apoptosis in GBM stem-like cells, which may be due to increased ROS and downregulation of both ALDH and the NFkB pathway. These data indicate that DS/copper may induce the intrinsic apoptotic pathway through modulation of the Bcl2 family, and it is also able to eliminate the stem-like cell population in GBM cell lines [242]. Another group reported the potentiated effect of DS in combination with copper. In particular, Hothi and collaborators evaluated its effect on glioma stem cells and showed increased apoptosis against CSCs specifically [219]. In addition, DS/copper reduced the chymotrypsin-like proteasomal activity in these cells, parallel with the inhibition of the ubiquitin-proteasome pathway and the consequent tumor cell death [219].

Another investigation indicated that DS/copper treatment in mammospheres strongly reduced the CSC population. DS in combination with copper generated ROS and triggered the downstream p38 MAPK and apoptosis-related cJun N-terminal kinase pathways. Furthermore, constitutive NFKB activity in breast CSCs was blocked by DS/copper [243].

DS abolished CSC features and totally reversed paclitaxel and cisplatin resistance in MDA-MB-231PAC10 cells (highly cross-resistant to paclitaxel and cisplatin) [244].

PF-03084014, a $\gamma$-secretase inhibitor, was able to inhibit the expression of survivin (IAP family protein) and MCL1 (antiapoptotic molecule) and reduce CSCs in triple-negative breast cancer models [220]. Sorafenib and FH535 ( $\beta$-catenin/Tcf inhibitor) impede liver CSC proliferation and growth by controlling survivin [221]. Similarly, STX-0119, an inhibitor of signal transducer and activator of transcription (STAT) 3, prevents the expression of STAT3 target genes, including survivin and c-Myc, leading to the apoptotic cell death of CSCs (derived from recurrent glioblastoma) [222].

At high doses, 4-diethylaminobenzaldehyde (DEAB), an aldehyde dehydrogenase inhibitor, can deplete CD133+ ovarian CSCs [157]. DEAB was able to significantly reduce spheroid size and proliferation of patient-derived endometrial CSCs [245]. Recently, it has been demonstrated that DEAB eradicates human pancreatic cancer stem-like cells, reducing cell viability and increasing cell apoptosis [223]. In colon cancer, a survivin inhibitor increased the sensitivity in the CD133 + cell segment to 5-fluorouracil [246].

Another synthetic inhibitor widely used in CSCs is the all-trans retinoic acid (ATRA), an active metabolite of vitamin A. It is implicated in numerous pivotal pathways such as the immune system, embryonic development, function, epithelial integrity, and reproduction [247]. It has been reported that ATRA constrains tumor cell growth by shifting cell cycle progression [224] and targets CSC spheroids both in vitro and in vivo [225]. ATRA decreased ALDH1 expression and inhibited in-vitro ovarian CSC spheroid size and cell invasion and migration; it also inhibited the tumorigenesis of ovarian cancers in vivo [225]. The authors indicate that the effects are due to the ability of ATRA to downregulate ALDH1/FoxM1/Notch1 signaling [225]. ATRA used in combination with gefitinib in cancer stem-cell-like adenocarcinoma decreased CSC-mediated resistance by reducing ALDH1A1 and CD44 expression and increasing the anticancer effects of gefitinib in NSCLC/ADC [248].

As mentioned above, autophagy is an adaptive mechanism necessary for CSC maintenance. Notably, CQ, an autophagy inhibitor, targeted pancreatic CSCs by inhibiting CXCR4 and autophagy by hedgehog signaling [226]. Salinomycin and metformin were also able to target CSCs in vitro and in vivo and to potentiate the effect of chemotherapeutics in 
inhibiting tumor growth and prolonging remission [249-251]. PTC-209, a BMI-1 inhibitor, prevented colorectal CSC self-renewal and inhibited tumor growth and progression in a mouse xenograft model [227].

Regarding necroptosis, different therapeutic approaches targeting this pathway have been reported. For instance, necroptosis was induced in breast CSCs by a $\mathrm{Ni}(\mathrm{II})$ dithiocarbamate phenanthroline complex [228]. Similarly, it has been reported that an Os(II) bathophenanthroline complex induced human breast CSC death, predominantly by necroptosis. This drug was able to selectively target mammospheres, reducing CSC proliferation and viability [229]. Notably, Chefetz and collaborators reported that a selective, panALDH1A family inhibitor, 673A (ALDH1Ai), activated necroptosis in $\mathrm{CD}_{133^{+}}$ovarian CSCs [157]. Necroptosis is due, in part, to the induction of mitochondrial uncoupling proteins and oxidative phosphorylation decrease. ALDH1Ai 637 is extremely synergistic with chemotherapy, removing chemotherapy-resistant tumors, counteracting tumor initiation and growth, and improving tumor eradication rates in patients [157]. These studies reinforced the role of ALDH1 family enzymes in chemoresistance and reinforced the hypothesis that therapeutic approaches targeting the ALDH family may ameliorate clinical outcomes in cancer patients.

\section{Discussion and Conclusions}

The evasion of programmed cell death represents a hallmark of human cancers. CSCs are the main character of this process since they are able to evade programmed cell death to promote their self-renewal, supporting survival in response to radio and chemotherapy. Basing on the uncovered evidence, a combination of modulators of programmed cell death and standard chemotherapeutic agents may be an efficient anticancer therapeutic approach. These combined therapies may contribute to counteracting chemotherapy resistance and sensitize CSCs to anticancer treatments. However, there are several points that need to be deeply investigated in order to develop an effective anticancer treatment targeting programmed cell death; in particular, it is necessary to consider the tumor microenvironment, cell type, stimuli and/or stress conditions, and tumor growth properties. Controlling the programmed cell death machinery (including apoptosis, autophagy, and necroptosis pathways) to eradicate CSCs has shown great potential. The suppression of their self-renewal, the selective induction of CSC differentiation, or the inhibition of CSC survival and growth by targeting microenvironment elements or key signaling molecules represent undoubtedly attractive investigations to cancer researchers. The selective eradication of cancer cells and, in particular, CSCs can be achieved with both synthetic and natural agents, used as single approaches or in combination with gold-standard chemotherapies that interfere with the deregulated cellular signals that promote CSCs. Additionally, targeted therapies reactivating cell death signaling in CSCs may show synergic effects with conventional therapies and enhance clinical efficacy.

Even if the reported studies are encouraging, further investigations are necessary to establish a combination of agents that is able to eradicate CSCs or inhibit their growth and proliferation.

Author Contributions: V.C. and M.d. wrote the manuscript with the support of A.C.; V.C. prepared the figure and table with the support of M.d.; M.d. organized the manuscript with the support of A.C.; A.G., F.G., and E.B. reviewed the manuscript; M.Q. helped with the bibliographic research. All authors have read and agreed to the published version of the manuscript.

Funding: This research received no external funding.

Conflicts of Interest: The authors declare no conflict of interest.

\section{References}

1. Nagai, H.; Kim, Y.H. Cancer Prevention from the Perspective of Global Cancer Burden Patterns. J. Thorac. Dis. 2017, 9, $448-451$. [CrossRef] [PubMed] 
2. Fidoamore, A.; Cristiano, L.; Antonosante, A.; d'Angelo, M.; Di Giacomo, E.; Astarita, C.; Giordano, A.; Ippoliti, R.; Benedetti, E.; Cimini, A. Glioblastoma Stem Cells Microenvironment: The Paracrine Roles of the Niche in Drug and Radioresistance. Stem Cells Int. 2016, 2016, 6809105. [CrossRef] [PubMed]

3. Duan, J.; Qiu, W.; Xu, S.; Wang, B.; Ye, X.; Ping, Y.; Zhang, X.; Bian, X.; Yu, S. Strategies for Isolating and Enriching Cancer Stem Cells: Well Begun Is Half Done. Stem Cells Dev. 2013, 22, 2221-2239. [CrossRef] [PubMed]

4. Al-Hajj, M.; Wicha, M.S.; Benito-Hernandez, A.; Morrison, S.J.; Clarke, M.F. Prospective Identification of Tumorigenic Breast Cancer Cells. Proc. Natl. Acad. Sci. USA 2003, 100, 3983-3988. [CrossRef] [PubMed]

5. Kim, C.F.B.; Jackson, E.L.; Woolfenden, A.E.; Lawrence, S.; Babar, I.; Vogel, S.; Crowley, D.; Bronson, R.T.; Jacks, T. Identification of Bronchioalveolar Stem Cells in Normal Lung and Lung Cancer. Cell 2005, 121, 823-835. [CrossRef]

6. Collins, A.T.; Berry, P.A.; Hyde, C.; Stower, M.J.; Maitland, N.J. Prospective Identification of Tumorigenic Prostate Cancer Stem Cells. Cancer Res. 2005, 65, 10946-10951. [CrossRef]

7. O'Brien, C.A.; Pollett, A.; Gallinger, S.; Dick, J.E. A Human Colon Cancer Cell Capable of Initiating Tumour Growth in Immunodeficient Mice. Nature 2007, 445, 106-110. [CrossRef]

8. Hemmati, H.D.; Nakano, I.; Lazareff, J.A.; Masterman-Smith, M.; Geschwind, D.H.; Bronner-Fraser, M.; Kornblum, H.I. Cancerous Stem Cells Can Arise from Pediatric Brain Tumors. Proc. Natl. Acad. Sci. USA 2003, 100, 15178-15183. [CrossRef]

9. Singh, S.K.; Clarke, I.D.; Terasaki, M.; Bonn, V.E.; Hawkins, C.; Squire, J.; Dirks, P.B. Identification of a Cancer Stem Cell in Human Brain Tumors. Cancer Res. 2003, 63, 5821-5828.

10. Han, J.; Won, M.; Kim, J.H.; Jung, E.; Min, K.; Jangili, P.; Kim, J.S. Cancer Stem Cell-Targeted Bio-Imaging and Chemotherapeutic Perspective. Chem. Soc. Rev. 2020, 49, 7856-7878. [CrossRef]

11. Kemper, K.; Grandela, C.; Medema, J.P. Molecular Identification and Targeting of Colorectal Cancer Stem Cells. Oncotarget 2010, 1, 387-395. [CrossRef] [PubMed]

12. Haraguchi, N.; Utsunomiya, T.; Inoue, H.; Tanaka, F.; Mimori, K.; Barnard, G.F.; Mori, M. Characterization of a Side Population of Cancer Cells from Human Gastrointestinal System. Stem Cells 2006, 24, 506-513. [CrossRef]

13. Scharenberg, C.W.; Harkey, M.A.; Torok-Storb, B. The ABCG2 Transporter Is an Efficient Hoechst 33342 Efflux Pump and Is Preferentially Expressed by Immature Human Hematopoietic Progenitors. Blood 2002, 99, 507-512. [CrossRef] [PubMed]

14. Patrawala, L.; Calhoun, T.; Schneider-Broussard, R.; Zhou, J.; Claypool, K.; Tang, D.G. Side Population Is Enriched in Tumorigenic, Stem-like Cancer Cells, Whereas ABCG2+ and ABCG2- Cancer Cells Are Similarly Tumorigenic. Cancer Res. 2005, 65, 6207-6219. [CrossRef] [PubMed]

15. Ding, Y.; Gao, H.; Zhang, Q. The Biomarkers of Leukemia Stem Cells in Acute Myeloid Leukemia. Stem Cell Investig. 2017, 4, 19. [CrossRef] [PubMed]

16. Haubner, S.; Perna, F.; Köhnke, T.; Schmidt, C.; Berman, S.; Augsberger, C.; Schnorfeil, F.M.; Krupka, C.; Lichtenegger, F.S.; Liu, X.; et al. Coexpression Profile of Leukemic Stem Cell Markers for Combinatorial Targeted Therapy in AML. Leukemia 2019, $33,64-74$. [CrossRef] [PubMed]

17. Hanekamp, D.; Cloos, J.; Schuurhuis, G.J. Leukemic Stem Cells: Identification and Clinical Application. Int. J. Hematol. 2017, 105, 549-557. [CrossRef]

18. Elbaiomy, M.A.; Akl, T.; Atwan, N.; Elsayed, A.A.; Elzaafarany, M.; Shamaa, S. Clinical Impact of Breast Cancer Stem Cells in Metastatic Breast Cancer Patients. J. Oncol. 2020, 2020, 2561726. [CrossRef]

19. Kong, Y.; Lyu, N.; Wu, J.; Tang, H.; Xie, X.; Yang, L.; Li, X.; Wei, W.; Xie, X. Breast Cancer Stem Cell Markers CD44 and ALDH1A1 in Serum: Distribution and Prognostic Value in Patients with Primary Breast Cancer. J. Cancer 2018, 9, 3728-3735. [CrossRef]

20. Ricardo, S.; Vieira, A.F.; Gerhard, R.; Leitao, D.; Pinto, R.; Cameselle-Teijeiro, J.F.; Milanezi, F.; Schmitt, F.; Paredes, J. Breast Cancer Stem Cell Markers CD44, CD24 and ALDH1: Expression Distribution within Intrinsic Molecular Subtype. J. Clin. Pathol. 2011, 64, 937-946. [CrossRef]

21. Lang, S.H.; Frame, F.M.; Collins, A.T. Prostate Cancer Stem Cells. J. Pathol. 2009, 217, 299-306. [CrossRef] [PubMed]

22. Qin, J.; Liu, X.; Laffin, B.; Chen, X.; Choy, G.; Jeter, C.; Calhoun-Davis, T.; Li, H.; Palapattu, G.S.; Pang, S.; et al. The PSA-/Lo Prostate Cancer Cell Population Harbors Self-Renewing Long-Term Tumor-Propagating Cells That Resist Castration. Cell Stem Cell 2012, 10, 556-569. [CrossRef] [PubMed]

23. Chen, X.; Rycaj, K.; Liu, X.; Tang, D.G. New Insights into Prostate Cancer Stem Cells. Cell Cycle 2013, 12, 579-586. [CrossRef] [PubMed]

24. Brinckerhoff, C.E. Cancer Stem Cells (CSCs) in Melanoma: There's Smoke, but Is There Fire?: Cancer Stem Cells in Melanoma. J. Cell. Physiol. 2017, 232, 2674-2678. [CrossRef] [PubMed]

25. Marzagalli, M.; Raimondi, M.; Fontana, F.; Montagnani Marelli, M.; Moretti, R.M.; Limonta, P. Cellular and Molecular Biology of Cancer Stem Cells in Melanoma: Possible Therapeutic Implications. Semin. Cancer Biol. 2019, 59, 221-235. [CrossRef]

26. Xu, H.-S.; Qin, X.-L.; Zong, H.-L.; He, X.-G.; Cao, L. Cancer Stem Cell Markers in Glioblastoma-An Update. Eur. Rev. Med. Pharmacol. Sci. 2017, 21, 3207-3211.

27. Behnan, J.; Stangeland, B.; Langella, T.; Finocchiaro, G.; Tringali, G.; Meling, T.R.; Murrell, W. Identification and Characterization of a New Source of Adult Human Neural Progenitors. Cell Death Dis. 2017, 8, e2991. [CrossRef]

28. Pruszak, J.; Ludwig, W.; Blak, A.; Alavian, K.; Isacson, O. CD15, CD24, and CD29 Define a Surface Biomarker Code for Neural Lineage Differentiation of Stem Cells. Stem Cells 2009, 27, 2928-2940. [CrossRef]

29. Kong, D.-S. Cancer Stem Cells in Brain Tumors and Their Lineage Hierarchy. Int. J. Stem Cells 2012, 5, 12-15. [CrossRef] 
30. Hardavella, G.; George, R.; Sethi, T. Lung Cancer Stem Cells-Characteristics, Phenotype. Transl. Lung Cancer Res. $2016,5,272-279$. [CrossRef]

31. Xiao, Y.; Lin, M.; Jiang, X.; Ye, J.; Guo, T.; Shi, Y.; Bian, X. The Recent Advances on Liver Cancer Stem Cells: Biomarkers, Separation, and Therapy. Anal. Cell. Pathol. 2017, 2017, 5108653. [CrossRef] [PubMed]

32. Chaudhari, P.; Tian, L.; Deshmukh, A.; Jang, Y.-Y. Expression Kinetics of Hepatic Progenitor Markers in Cellular Models of Human Liver Development Recapitulating Hepatocyte and Biliary Cell Fate Commitment. Exp. Biol. Med. 2016, 241, 1653-1662. [CrossRef] [PubMed]

33. Zhang, R.-R.; Zheng, Y.-W.; Li, B.; Nie, Y.-Z.; Ueno, Y.; Tsuchida, T.; Taniguchi, H. Hepatic Stem Cells with Self-Renewal and Liver Repopulation Potential Are Harbored in CDCP1-Positive Subpopulations of Human Fetal Liver Cells. Stem Cell Res. Ther. 2018, 9 , 29. [CrossRef] [PubMed]

34. Habib, M.; Saif, M.W. Pancreatic Cancer Stem Cells: Their Role in Pancreatic Cancer Patient Outcomes and What Is Future? JOP 2013, 14, 401-404. [CrossRef] [PubMed]

35. Ishiwata, T.; Matsuda, Y.; Yoshimura, H.; Sasaki, N.; Ishiwata, S.; Ishikawa, N.; Takubo, K.; Arai, T.; Aida, J. Pancreatic Cancer Stem Cells: Features and Detection Methods. Pathol. Oncol. Res. 2018, 24, 797-805. [CrossRef] [PubMed]

36. Gzil, A.; Zarębska, I.; Bursiewicz, W.; Antosik, P.; Grzanka, D.; Szylberg, Ł. Markers of Pancreatic Cancer Stem Cells and Their Clinical and Therapeutic Implications. Mol. Biol. Rep. 2019, 46, 6629-6645. [CrossRef] [PubMed]

37. Huling, J.; Yoo, J.J. Comparing Adult Renal Stem Cell Identification, Characterization and Applications. J. Biomed. Sci. 2017, 24. [CrossRef]

38. Wang, H.; Gomez, J.A.; Klein, S.; Zhang, Z.; Seidler, B.; Yang, Y.; Schmeckpeper, J.; Zhang, L.; Muramoto, G.G.; Chute, J.; et al. Adult Renal Mesenchymal Stem Cell-Like Cells Contribute to Juxtaglomerular Cell Recruitment. J. Am. Soc. Nephrol. 2013, 24, 1263-1273. [CrossRef]

39. Klemba, A.; Purzycka-Olewiecka, J.K.; Wcisło, G.; Czarnecka, A.M.; Lewicki, S.; Lesyng, B.; Szczylik, C.; Kieda, C. Surface Markers of Cancer Stem-like Cells of Ovarian Cancer and Their Clinical Relevance. Contemp. Oncol. 2018, 22, 48-55. [CrossRef]

40. Parte, S.C.; Batra, S.K.; Kakar, S.S. Characterization of Stem Cell and Cancer Stem Cell Populations in Ovary and Ovarian Tumors. J. Ovarian Res. 2018, 11, 69. [CrossRef]

41. Bao, B.; Ahmad, A.; Azmi, A.S.; Ali, S.; Sarkar, F.H. Cancer Stem Cells (CSCs) and Mechanisms of Their Regulation: Implications for Cancer Therapy. Curr. Protoc. Pharmacol. 2013, 61. [CrossRef] [PubMed]

42. Ayob, A.Z.; Ramasamy, T.S. Cancer Stem Cells as Key Drivers of Tumour Progression. J. Biomed. Sci. 2018, 25. [CrossRef] [PubMed]

43. Fidoamore, A.; Cristiano, L.; Laezza, C.; Galzio, R.; Benedetti, E.; Cinque, B.; Antonosante, A.; d'Angelo, M.; Castelli, V.; Cifone, M.G.; et al. Energy Metabolism in Glioblastoma Stem Cells: PPAR $\alpha$ a Metabolic Adaptor to Intratumoral Microenvironment. Oncotarget 2017, 8, 108430-108450. [CrossRef] [PubMed]

44. Desai, A.; Yan, Y.; Gerson, S.L. Concise Reviews: Cancer Stem Cell Targeted Therapies: Toward Clinical Success. Stem Cells Transl. Med. 2019, 8, 75-81. [CrossRef]

45. Sun, H.-R.; Wang, S.; Yan, S.-C.; Zhang, Y.; Nelson, P.J.; Jia, H.-L.; Qin, L.-X.; Dong, Q.-Z. Therapeutic Strategies Targeting Cancer Stem Cells and Their Microenvironment. Front. Oncol. 2019, 9. [CrossRef]

46. Plaks, V.; Kong, N.; Werb, Z. The Cancer Stem Cell Niche: How Essential Is the Niche in Regulating Stemness of Tumor Cells? Cell Stem Cell 2015, 16, 225-238. [CrossRef]

47. Zhao, Y.; Dong, Q.; Li, J.; Zhang, K.; Qin, J.; Zhao, J.; Sun, Q.; Wang, Z.; Wartmann, T.; Jauch, K.W.; et al. Targeting Cancer Stem Cells and Their Niche: Perspectives for Future Therapeutic Targets and Strategies. Semin. Cancer Biol. 2018, 53, 139-155. [CrossRef]

48. Ciardiello, C.; Leone, A.; Budillon, A. The Crosstalk between Cancer Stem Cells and Microenvironment Is Critical for Solid Tumor Progression: The Significant Contribution of Extracellular Vesicles. Available online: https://www.hindawi.com/journals/sci/ 2018/6392198/ (accessed on 30 December 2020).

49. Ye, J.; Wu, D.; Wu, P.; Chen, Z.; Huang, J. The Cancer Stem Cell Niche: Cross Talk between Cancer Stem Cells and Their Microenvironment. Tumor Biol. 2014, 35, 3945-3951. [CrossRef]

50. Tang, D.; Kang, R.; Berghe, T.V.; Vandenabeele, P.; Kroemer, G. The Molecular Machinery of Regulated Cell Death. Cell Res. 2019, 29, 347-364. [CrossRef]

51. Safa, A.R. Resistance to Cell Death and Its Modulation in Cancer Stem Cells. Crit. Rev. Oncog. 2016, 21, 203-219. [CrossRef]

52. Kim, R.; Emi, M.; Tanabe, K. The Role of Apoptosis in Cancer Cell Survival and Therapeutic Outcome. Cancer Biol. Ther. 2006, 5, 1429-1442. [CrossRef] [PubMed]

53. Granados, K.; Poelchen, J.; Novak, D.; Utikal, J. Cellular Reprogramming-A Model for Melanoma Cellular Plasticity. Int. J. Mol. Sci. 2020, 21, 8274. [CrossRef] [PubMed]

54. Calabrese, C.; Poppleton, H.; Kocak, M.; Hogg, T.L.; Fuller, C.; Hamner, B.; Oh, E.Y.; Gaber, M.W.; Finklestein, D.; Allen, M.; et al. A Perivascular Niche for Brain Tumor Stem Cells. Cancer Cell 2007, 11, 69-82. [CrossRef] [PubMed]

55. Emmink, B.L.; Van Houdt, W.J.; Vries, R.G.; Hoogwater, F.J.H.; Govaert, K.M.; Verheem, A.; Nijkamp, M.W.; Steller, E.J.A.; Jimenez, C.R.; Clevers, H.; et al. Differentiated Human Colorectal Cancer Cells Protect Tumor-Initiating Cells from Irinotecan. Gastroenterology 2011, 141, 269-278. [CrossRef] 
56. Huang, Z.; Wu, T.; Liu, A.Y.; Ouyang, G. Differentiation and Transdifferentiation Potentials of Cancer Stem Cells. Oncotarget 2015, 6, 39550-39563. [CrossRef]

57. García-Heredia, J.M.; Carnero, A. Role of Mitochondria in Cancer Stem Cell Resistance. Cells 2020, 9, 1693. [CrossRef]

58. Visvader, J.E.; Lindeman, G.J. Cancer Stem Cells in Solid Tumours: Accumulating Evidence and Unresolved Questions. Nat. Rev. Cancer 2008, 8, 755-768. [CrossRef]

59. Phi, L.T.H.; Sari, I.N.; Yang, Y.-G.; Lee, S.-H.; Jun, N.; Kim, K.S.; Lee, Y.K.; Kwon, H.Y. Cancer Stem Cells (CSCs) in Drug Resistance and Their Therapeutic Implications in Cancer Treatment. Stem Cells Int. 2018, 2018. [CrossRef]

60. Hongmei, Z. Extrinsic and Intrinsic Apoptosis Signal Pathway Review. In Apoptosis and Medicine; Ntuli, T., Ed.; InTech: London, UK, 2012; ISBN 978-953-51-0701-9.

61. Pfeffer, C.M.; Singh, A.T.K. Amareshwar Singh Apoptosis: A Target for Anticancer Therapy. Int. J. Mol. Sci. 2018, 19, 448. [CrossRef]

62. Suhaili, S.H.; Karimian, H.; Stellato, M.; Lee, T.-H.; Aguilar, M.-I. Mitochondrial Outer Membrane Permeabilization: A Focus on the Role of Mitochondrial Membrane Structural Organization. Biophys. Rev. 2017, 9, 443-457. [CrossRef]

63. Pazzaglia, S.; Pioli, C. Multifaceted Role of PARP-1 in DNA Repair and Inflammation: Pathological and Therapeutic Implications in Cancer and Non-Cancer Diseases. Cells 2019, 9, 41. [CrossRef] [PubMed]

64. Tait, S.W.G.; Green, D.R. Caspase-Independent Cell Death: Leaving the Set without the Final Cut. Oncogene 2008, $27,6452-6461$. [CrossRef] [PubMed]

65. Roumane, A.; Berthenet, K.; El Fassi, C.; Ichim, G. Caspase-Independent Cell Death Does Not Elicit a Proliferative Response in Melanoma Cancer Cells. BMC Cell Biology 2018, 19. [CrossRef] [PubMed]

66. Kalkavan, H.; Green, D.R. MOMP, Cell Suicide as a BCL-2 Family Business. Cell Death Differ. 2018, 25, 46-55. [CrossRef]

67. Tait, S.W.G.; Parsons, M.J.; Llambi, F.; Bouchier-Hayes, L.; Connell, S.; Muñoz-Pinedo, C.; Green, D.R. Resistance to CaspaseIndependent Cell Death Requires Persistence of Intact Mitochondria. Dev. Cell 2010, 18, 802-813. [CrossRef]

68. Guha, M.; Srinivasan, S.; Ruthel, G.; Kashina, A.K.; Carstens, R.P.; Mendoza, A.; Khanna, C.; Van Winkle, T.; Avadhani, N.G. Mitochondrial Retrograde Signaling Induces Epithelial-Mesenchymal Transition and Generates Breast Cancer Stem Cells. Oncogene 2014, 33, 5238-5250. [CrossRef]

69. Lee, C.-H.; Wu, S.-B.; Hong, C.-H.; Liao, W.-T.; Wu, C.-Y.; Chen, G.-S.; Wei, Y.-H.; Yu, H.-S. Aberrant Cell Proliferation by Enhanced Mitochondrial Biogenesis via MtTFA in Arsenical Skin Cancers. Am. J. Pathol. 2011, 178, 2066-2076. [CrossRef]

70. Guerra, F.; Kurelac, I.; Cormio, A.; Zuntini, R.; Amato, L.B.; Ceccarelli, C.; Santini, D.; Cormio, G.; Fracasso, F.; Selvaggi, L.; et al. Placing Mitochondrial DNA Mutations within the Progression Model of Type I Endometrial Carcinoma. Hum. Mol. Genet. 2011, 20, 2394-2405. [CrossRef]

71. Ichim, G.; Tait, S.W.G. A Fate Worse than Death: Apoptosis as an Oncogenic Process. Nat. Rev. Cancer 2016, 16, 539-548. [CrossRef]

72. Xu, Y.; So, C.; Lam, H.-M.; Fung, M.-C.; Tsang, S.-Y. Apoptosis Reversal Promotes Cancer Stem Cell-Like Cell Formation. Neoplasia 2018, 20, 295-303. [CrossRef]

73. Zhou, M.; Liu, X.; Li, Z.; Huang, Q.; Li, F.; Li, C.-Y. Caspase-3 Regulates the Migration, Invasion and Metastasis of Colon Cancer Cells. Int. J. Cancer 2018, 143, 921-930. [CrossRef] [PubMed]

74. Berthenet, K.; Castillo Ferrer, C.; Fanfone, D.; Popgeorgiev, N.; Neves, D.; Bertolino, P.; Gibert, B.; Hernandez-Vargas, H.; Ichim, G. Failed Apoptosis Enhances Melanoma Cancer Cell Aggressiveness. Cell Rep. 2020, 31, 107731. [CrossRef] [PubMed]

75. Guicciardi, M.E.; Gores, G.J. Life and Death by Death Receptors. FASEB J. 2009, 23, 1625-1637. [CrossRef] [PubMed]

76. Kinsella, S.; Prehn, J.H.M. In the Middle of a Chain Interaction. Mol. Cell 2016, 64, 217-218. [CrossRef]

77. Lafont, E. Stress Management: Death Receptor Signalling and Cross-Talks with the Unfolded Protein Response in Cancer. Cancers 2020, 12, 1113. [CrossRef]

78. Ting, A.T.; Bertrand, M.J.M. More to Life than NF-KB in TNFR1 Signaling. Trends Immunol. 2016, 37, 535-545. [CrossRef]

79. Annibaldi, A.; Walczak, H. Death Receptors and Their Ligands in Inflammatory Disease and Cancer. Cold Spring Harb. Perspect. Biol. 2020, 12. [CrossRef]

80. Medler, J.; Wajant, H. Tumor Necrosis Factor Receptor-2 (TNFR2): An Overview of an Emerging Drug Target. Expert Opin. Ther. Targets 2019, 23, 295-307. [CrossRef]

81. Wajant, H.; Siegmund, D. TNFR1 and TNFR2 in the Control of the Life and Death Balance of Macrophages. Front. Cell Dev. Biol. 2019, 7, 91. [CrossRef]

82. Pistritto, G.; Trisciuoglio, D.; Ceci, C.; Garufi, A.; D'Orazi, G. Apoptosis as Anticancer Mechanism: Function and Dysfunction of Its Modulators and Targeted Therapeutic Strategies. Aging 2016, 8, 603-619. [CrossRef]

83. Carneiro, B.A.; El-Deiry, W.S. Targeting Apoptosis in Cancer Therapy. Nat. Rev. Clin. Oncol. 2020, 17, 395-417. [CrossRef] [PubMed]

84. Robey, R.W.; Pluchino, K.M.; Hall, M.D.; Fojo, A.T.; Bates, S.E.; Gottesman, M.M. Revisiting the Role of ABC Transporters in Multidrug-Resistant Cancer. Nat. Rev. Cancer 2018, 18, 452-464. [CrossRef] [PubMed]

85. Lu, J.F.; Pokharel, D.; Bebawy, M. MRP1 and Its Role in Anticancer Drug Resistance. Drug Metab. Rev. 2015, 47, 406-419. [CrossRef] [PubMed]

86. Wilson, B.J.; Saab, K.R.; Ma, J.; Schatton, T.; Pütz, P.; Zhan, Q.; Murphy, G.F.; Gasser, M.; Waaga-Gasser, A.M.; Frank, N.Y.; et al. ABCB5 Maintains Melanoma-Initiating Cells through a Proinflammatory Cytokine Signaling Circuit. Cancer Res. 2014, 74, 4196-4207. [CrossRef] 
87. Jaramillo, A.C.; Cloos, J.; Lemos, C.; Stam, R.W.; Kaspers, G.J.L.; Jansen, G.; Peters, G.J. Ex Vivo Resistance in Childhood Acute Lymphoblastic Leukemia: Correlations between BCRP, MRP1, MRP4 and MRP5 ABC Transporter Expression and Intracellular Methotrexate Polyglutamate Accumulation. Leuk. Res. 2019, 79, 45-51. [CrossRef]

88. Hodges, L.M.; Markova, S.M.; Chinn, L.W.; Gow, J.M.; Kroetz, D.L.; Klein, T.E.; Altman, R.B. Very Important Pharmacogene Summary: ABCB1 (MDR1, P-Glycoprotein). Pharm. Genom. 2011, 21, 152-161. [CrossRef]

89. Nakai, E.; Park, K.; Yawata, T.; Chihara, T.; Kumazawa, A.; Nakabayashi, H.; Shimizu, K. Enhanced MDR1 Expression and Chemoresistance of Cancer Stem Cells Derived from Glioblastoma. Cancer Investig. 2009, 27, 901-908. [CrossRef]

90. Rentala, S.; Mangamoori, L.N. Isolation, Characterization and Mobilization of Prostate Cancer Tissue Derived CD133+ MDR1+ Cells. J. Stem Cells 2010, 5, 75-81.

91. Stacy, A.E.; Jansson, P.J.; Richardson, D.R. Molecular Pharmacology of ABCG2 and Its Role in Chemoresistance. Mol. Pharmacol. 2013, 84, 655-669. [CrossRef]

92. Xie, Z.-Y.; Lv, K.; Xiong, Y.; Guo, W.-H. ABCG2-Meditated Multidrug Resistance and Tumor-Initiating Capacity of Side Population Cells from Colon Cancer. Oncol. Res. Treat. 2014, 37, 666-668, 670-672. [CrossRef]

93. Xi, G.; Hayes, E.; Lewis, R.; Ichi, S.; Mania-Farnell, B.; Shim, K.; Takao, T.; Allender, E.; Mayanil, C.S.; Tomita, T. CD133 and DNA-PK Regulate MDR1 via the PI3K- or Akt-NF-KB Pathway in Multidrug-Resistant Glioblastoma Cells in Vitro. Oncogene 2016, 35, 241-250. [CrossRef] [PubMed]

94. Suresh, R.; Ali, S.; Ahmad, A.; Philip, P.A.; Sarkar, F.H. The Role of Cancer Stem Cells in Recurrent and Drug-Resistant Lung Cancer. Adv. Exp. Med. Biol. 2016, 890, 57-74. [CrossRef] [PubMed]

95. Toledo-Guzmán, M.E.; Bigoni-Ordóñez, G.D.; Ibáñez Hernández, M.; Ortiz-Sánchez, E. Cancer Stem Cell Impact on Clinical Oncology. World J. Stem Cells 2018, 10, 183-195. [CrossRef] [PubMed]

96. Yang, L.; Shi, P.; Zhao, G.; Xu, J.; Peng, W.; Zhang, J.; Zhang, G.; Wang, X.; Dong, Z.; Chen, F.; et al. Targeting Cancer Stem Cell Pathways for Cancer Therapy. Signal Transduct. Target. Ther. 2020, 5. [CrossRef] [PubMed]

97. Xia, P.; Xu, X.-Y. PI3K/Akt/MTOR Signaling Pathway in Cancer Stem Cells: From Basic Research to Clinical Application. Am. J. Cancer Res. 2015, 5, 1602-1609.

98. Yang, S.H.; Li, S.; Lu, G.; Xue, H.; Kim, D.H.; Zhu, J.-J.; Liu, Y. Metformin Treatment Reduces Temozolomide Resistance of Glioblastoma Cells. Oncotarget 2016, 7, 78787-78803. [CrossRef]

99. Chen, J.; Shao, R.; Li, F.; Monteiro, M.; Liu, J.-P.; Xu, Z.P.; Gu, W. PI3K/Akt/MTOR Pathway Dual Inhibitor BEZ235 Suppresses the Stemness of Colon Cancer Stem Cells. Clin. Exp. Pharmacol. Physiol. 2015, 42, 1317-1326. [CrossRef]

100. Knight, T.; Luedtke, D.; Edwards, H.; Taub, J.W.; Ge, Y. A Delicate Balance-The BCL-2 Family and Its Role in Apoptosis, Oncogenesis, and Cancer Therapeutics. Biochem. Pharmacol. 2019, 162, 250-261. [CrossRef]

101. Hata, A.N.; Engelman, J.A.; Faber, A.C. The BCL2 Family: Key Mediators of the Apoptotic Response to Targeted Anticancer Therapeutics. Cancer Discov. 2015, 5, 475-487. [CrossRef]

102. Ryoo, I.; Lee, S.; Kwak, M.-K. Redox Modulating NRF2: A Potential Mediator of Cancer Stem Cell Resistance. Oxid. Med. Cell Longev. 2016, 2016, 2428153. [CrossRef]

103. Hu, Y.; Yagüe, E.; Zhao, J.; Wang, L.; Bai, J.; Yang, Q.; Pan, T.; Zhao, H.; Liu, J.; Zhang, J. Sabutoclax, Pan-Active BCL-2 Protein Family Antagonist, Overcomes Drug Resistance and Eliminates Cancer Stem Cells in Breast Cancer. Cancer Lett. 2018, 423, 47-59. [CrossRef] [PubMed]

104. Li, Z.; Yuan, W.; Lin, Z. Functional Roles in Cell Signaling of Adaptor Protein TRADD from a Structural Perspective. Comput. Struct. Biotechnol. J. 2020, 18, 2867-2876. [CrossRef] [PubMed]

105. Grimm, S. The ER-Mitochondria Interface: The Social Network of Cell Death. Biochim. Biophys Acta 2012, 1823, 327-334. [CrossRef] [PubMed]

106. Soleimani, A.; Rahmani, F.; Ferns, G.A.; Ryzhikov, M.; Avan, A.; Hassanian, S.M. Role of the NF-KB Signaling Pathway in the Pathogenesis of Colorectal Cancer. Gene 2020, 726, 144132. [CrossRef]

107. Xia, L.; Tan, S.; Zhou, Y.; Lin, J.; Wang, H.; Oyang, L.; Tian, Y.; Liu, L.; Su, M.; Wang, H.; et al. Role of the NF\&kappa;B-Signaling Pathway in Cancer. OncoTargets Ther. 2018, 11, 2063-2073. [CrossRef]

108. Liu, T.; Zhang, L.; Joo, D.; Sun, S.-C. NF-KB Signaling in Inflammation. Signal Transduct. Target. Ther. 2017, 2. [CrossRef]

109. Xia, Z.-B.; Meng, F.-R.; Fang, Y.-X.; Wu, X.; Zhang, C.-W.; Liu, Y.; Liu, D.; Li, G.-Q.; Feng, F.-B.; Qiu, H.-Y. Inhibition of NF-KB Signaling Pathway Induces Apoptosis and Suppresses Proliferation and Angiogenesis of Human Fibroblast-like Synovial Cells in Rheumatoid Arthritis. Medicine 2018, 97. [CrossRef]

110. Chakraborty, S.; Li, L.; Tang, H.; Xie, Y.; Puliyappadamba, V.T.; Raisanen, J.; Burma, S.; Boothman, D.A.; Cochran, B.; Wu, J.; et al. Cytoplasmic TRADD Confers a Worse Prognosis in Glioblastoma. Neoplasia 2013, 15, 888-897. [CrossRef]

111. Carlisi, D.; Buttitta, G.; Di Fiore, R.; Scerri, C.; Drago-Ferrante, R.; Vento, R.; Tesoriere, G. Parthenolide and DMAPT Exert Cytotoxic Effects on Breast Cancer Stem-like Cells by Inducing Oxidative Stress, Mitochondrial Dysfunction and Necrosis. Cell Death Dis. 2016, 7, e2194. [CrossRef]

112. Sztiller-Sikorska, M.; Czyz, M. Parthenolide as Cooperating Agent for Anti-Cancer Treatment of Various Malignancies. Pharmaceuticals 2020,13, 194. [CrossRef]

113. Schimmer, A.D. Inhibitor of Apoptosis Proteins: Translating Basic Knowledge into Clinical Practice. Cancer Res. 2004, 64, 7183-7190. [CrossRef] [PubMed] 
114. Wu, T.Y.H.; Wagner, K.W.; Bursulaya, B.; Schultz, P.G.; Deveraux, Q.L. Development and Characterization of Nonpeptidic Small Molecule Inhibitors of the XIAP/Caspase-3 Interaction. Chem. Biol. 2003, 10, 759-767. [CrossRef]

115. Wang, Y.-H.; Scadden, D.T. Harnessing the Apoptotic Programs in Cancer Stem-like Cells. EMBO Rep. 2015, 16, 1084-1098. [CrossRef] [PubMed]

116. Grzybowska-Izydorczyk, O.; Cebula, B.; Robak, T.; Smolewski, P. Expression and Prognostic Significance of the Inhibitor of Apoptosis Protein (IAP) Family and Its Antagonists in Chronic Lymphocytic Leukaemia. Eur. J. Cancer 2010, 46, 800-810. [CrossRef] [PubMed]

117. Chen, X.; Wang, T.; Yang, D.; Wang, J.; Li, X.; He, Z.; Chen, F.; Che, X.; Song, X. Expression of the IAP Protein Family Acts Cooperatively to Predict Prognosis in Human Bladder Cancer Patients. Oncol. Lett. 2013, 5, 1278-1284. [CrossRef] [PubMed]

118. Xiao, R.; Allen, C.T.; Tran, L.; Patel, P.; Park, S.-J.; Chen, Z.; Van Waes, C.; Schmitt, N.C. Antagonist of CIAP1/2 and XIAP Enhances Anti-Tumor Immunity When Combined with Radiation and PD-1 Blockade in a Syngeneic Model of Head and Neck Cancer. Oncoimmunology 2018, 7, e1471440. [CrossRef] [PubMed]

119. Lalaoui, N.; Vaux, D.L. Recent Advances in Understanding Inhibitor of Apoptosis Proteins. F1000Res 2018, 7. [CrossRef]

120. Ward, G.A.; Lewis, E.J.; Ahn, J.S.; Johnson, C.N.; Lyons, J.F.; Martins, V.; Munck, J.M.; Rich, S.J.; Smyth, T.; Thompson, N.T.; et al. ASTX660, a Novel Non-Peptidomimetic Antagonist of CIAP1/2 and XIAP, Potently Induces TNF $\alpha$-Dependent Apoptosis in Cancer Cell Lines and Inhibits Tumor Growth. Mol. Cancer Ther. 2018, 17, 1381-1391. [CrossRef]

121. Abbas, R.; Larisch, S. Targeting XIAP for Promoting Cancer Cell Death-The Story of ARTS and SMAC. Cells 2020, 9, 663. [CrossRef]

122. Mohamed, M.S.; Bishr, M.K.; Almutairi, F.M.; Ali, A.G. Inhibitors of Apoptosis: Clinical Implications in Cancer. Apoptosis 2017, 22, 1487-1509. [CrossRef]

123. Eckelman, B.P.; Salvesen, G.S.; Scott, F.L. Human Inhibitor of Apoptosis Proteins: Why XIAP Is the Black Sheep of the Family. EMBO Rep. 2006, 7, 988-994. [CrossRef] [PubMed]

124. Cheung, C.H.A.; Chang, Y.-C.; Lin, T.-Y.; Cheng, S.M.; Leung, E. Anti-Apoptotic Proteins in the Autophagic World: An Update on Functions of XIAP, Survivin, and BRUCE. J. Biomed. Sci. 2020, 27. [CrossRef] [PubMed]

125. Scott, F.L.; Denault, J.-B.; Riedl, S.J.; Shin, H.; Renatus, M.; Salvesen, G.S. XIAP Inhibits Caspase-3 and -7 Using Two Binding Sites: Evolutionarily Conserved Mechanism of IAPs. EMBO J. 2005, 24, 645-655. [CrossRef]

126. Ji, J.; Yu, Y.; Li, Z.-L.; Chen, M.-Y.; Deng, R.; Huang, X.; Wang, G.-F.; Zhang, M.-X.; Yang, Q.; Ravichandran, S.; et al. XIAP Limits Autophagic Degradation of Sox2 and Is A Therapeutic Target in Nasopharyngeal Carcinoma Stem Cells. Theranostics 2018, 8 , 1494-1510. [CrossRef] [PubMed]

127. Vellanki, S.H.K.; Grabrucker, A.; Liebau, S.; Proepper, C.; Eramo, A.; Braun, V.; Boeckers, T.; Debatin, K.-M.; Fulda, S. SmallMolecule XIAP Inhibitors Enhance Gamma-Irradiation-Induced Apoptosis in Glioblastoma. Neoplasia 2009, 11, 743-752. [CrossRef]

128. Zobalova, R.; Stantic, M.; Prokopova, K.; Dong, L.-F.; Neuzil, J. Cancer Cells with High Expression of CD133 Exert FLIP Upregulation and Resistance to TRAIL-Induced Apoptosis. Biofactors 2008, 34, 231-235. [CrossRef]

129. Barzegar Behrooz, A.; Syahir, A.; Ahmad, S. CD133: Beyond a Cancer Stem Cell Biomarker. J. Drug Target. 2019, 27, 257-269. [CrossRef]

130. Llobet, D.; Eritja, N.; Yeramian, A.; Pallares, J.; Sorolla, A.; Domingo, M.; Santacana, M.; Gonzalez-Tallada, F.J.; Matias-Guiu, X.; Dolcet, $X$. The Multikinase Inhibitor Sorafenib Induces Apoptosis and Sensitises Endometrial Cancer Cells to TRAIL by Different Mechanisms. Eur. J. Cancer 2010, 46, 836-850. [CrossRef]

131. Piggott, L.; Omidvar, N.; Pérez, S.M.; Eberl, M.; Clarkson, R.W. Suppression of Apoptosis Inhibitor C-FLIP Selectively Eliminates Breast Cancer Stem Cell Activity in Response to the Anti-Cancer Agent, TRAIL. Breast Cancer Res. 2011, 13. [CrossRef]

132. Coudre, C.; Alani, J.; Ritchie, W.; Marsaud, V.; Sola, B.; Cahu, J. HIF-1 $\alpha$ and Rapamycin Act as Gerosuppressant in Multiple Myeloma Cells upon Genotoxic Stress. Cell Cycle 2016, 15, 2174-2182. [CrossRef]

133. Maugeri-Saccà, M.; Bartucci, M.; De Maria, R. DNA Damage Repair Pathways in Cancer Stem Cells. Mol. Cancer Ther. 2012, 11, 1627-1636. [CrossRef] [PubMed]

134. Ogasawara, M.A.; Zhang, H. Redox Regulation and Its Emerging Roles in Stem Cells and Stem-like Cancer Cells. Antioxid Redox Signal. 2009, 11, 1107-1122. [CrossRef] [PubMed]

135. Manic, G.; Sistigu, A.; Corradi, F.; Musella, M.; De Maria, R.; Vitale, I. Replication Stress Response in Cancer Stem Cells as a Target for Chemotherapy. Semin. Cancer Biol. 2018, 53, 31-41. [CrossRef] [PubMed]

136. Bartucci, M.; Svensson, S.; Romania, P.; Dattilo, R.; Patrizii, M.; Signore, M.; Navarra, S.; Lotti, F.; Biffoni, M.; Pilozzi, E.; et al. Therapeutic Targeting of Chk1 in NSCLC Stem Cells during Chemotherapy. Cell Death Differ. 2012, 19, 768-778. [CrossRef]

137. Elgendy, S.M.; Alyammahi, S.K.; Alhamad, D.W.; Abdin, S.M.; Omar, H.A. Ferroptosis: An Emerging Approach for Targeting Cancer Stem Cells and Drug Resistance. Crit. Rev. Oncol. Hematol. 2020, 155, 103095. [CrossRef]

138. Ye, Z.; Liu, W.; Zhuo, Q.; Hu, Q.; Liu, M.; Sun, Q.; Zhang, Z.; Fan, G.; Xu, W.; Ji, S.; et al. Ferroptosis: Final Destination for Cancer? Cell Prolif. 2020, 53. [CrossRef]

139. Raggi, C.; Gammella, E.; Correnti, M.; Buratti, P.; Forti, E.; Andersen, J.B.; Alpini, G.; Glaser, S.; Alvaro, D.; Invernizzi, P.; et al. Dysregulation of Iron Metabolism in Cholangiocarcinoma Stem-like Cells. Sci. Rep. 2017, 7, 17667. [CrossRef]

140. Bisaro, B.; Mandili, G.; Poli, A.; Piolatto, A.; Papa, V.; Novelli, F.; Cenacchi, G.; Forni, M.; Zanini, C. Proteomic Analysis of Extracellular Vesicles from Medullospheres Reveals a Role for Iron in the Cancer Progression of Medulloblastoma. Mol. Cell. Ther. 2015, 3. [CrossRef] 
141. Recalcati, S.; Gammella, E.; Cairo, G. Dysregulation of Iron Metabolism in Cancer Stem Cells. Free. Radic. Biol. Med. 2019, 133, 216-220. [CrossRef]

142. Basuli, D.; Tesfay, L.; Deng, Z.; Paul, B.; Yamamoto, Y.; Ning, G.; Xian, W.; McKeon, F.; Lynch, M.; Crum, C.P.; et al. Iron Addiction: A Novel Therapeutic Target in Ovarian Cancer. Oncogene 2017, 36, 4089-4099. [CrossRef]

143. Schonberg, D.L.; Miller, T.E.; Wu, Q.; Flavahan, W.A.; Das, N.K.; Hale, J.S.; Hubert, C.G.; Mack, S.C.; Jarrar, A.M.; Karl, R.T.; et al Preferential Iron Trafficking Characterizes Glioblastoma Stem-like Cells. Cancer Cell 2015, 28, 441-455. [CrossRef] [PubMed]

144. Chitambar, C.R.; Al-Gizawiy, M.M.; Alhajala, H.S.; Pechman, K.R.; Wereley, J.P.; Wujek, R.; Clark, P.A.; Kuo, J.S.; Antholine, W.E.; Schmainda, K.M. Gallium Maltolate Disrupts Tumor Iron Metabolism and Retards the Growth of Glioblastoma by Inhibiting Mitochondrial Function and Ribonucleotide Reductase. Mol. Cancer Ther. 2018, 17, 1240-1250. [CrossRef] [PubMed]

145. Müller, S.; Sindikubwabo, F.; Cañeque, T.; Lafon, A.; Versini, A.; Lombard, B.; Loew, D.; Wu, T.-D.; Ginestier, C.; Charafe-Jauffret, E.; et al. CD44 Regulates Epigenetic Plasticity by Mediating Iron Endocytosis. Nat. Chem. 2020, 12, 929-938. [CrossRef] [PubMed]

146. Seehawer, M.; Heinzmann, F.; D’Artista, L.; Harbig, J.; Roux, P.-F.; Hoenicke, L.; Dang, H.; Klotz, S.; Robinson, L.; Doré, G.; et al. Necroptosis Microenvironment Directs Lineage Commitment in Liver Cancer. Nature 2018, 562, 69-75. [CrossRef]

147. Stoll, G.; Ma, Y.; Yang, H.; Kepp, O.; Zitvogel, L.; Kroemer, G. Pro-Necrotic Molecules Impact Local Immunosurveillance in Human Breast Cancer. Oncoimmunology 2017, 6, e1299302. [CrossRef]

148. Berghe, T.V.; Linkermann, A.; Jouan-Lanhouet, S.; Walczak, H.; Vandenabeele, P. Regulated Necrosis: The Expanding Network of Non-Apoptotic Cell Death Pathways. Nat. Rev. Mol. Cell Biol. 2014, 15, 135-147. [CrossRef]

149. Dhuriya, Y.K.; Sharma, D. Necroptosis: A Regulated Inflammatory Mode of Cell Death. J. Neuroinflammation 2018, 15. [CrossRef]

150. Park, S.; Hatanpaa, K.J.; Xie, Y.; Mickey, B.E.; Madden, C.J.; Raisanen, J.M.; Ramnarain, D.B.; Xiao, G.; Saha, D.; Boothman, D.A.; et al. The Receptor Interacting Protein 1 Inhibits P53 Induction through NF-KappaB Activation and Confers a Worse Prognosis in Glioblastoma. Cancer Res. 2009, 69, 2809-2816. [CrossRef]

151. McCormick, K.D.; Ghosh, A.; Trivedi, S.; Wang, L.; Coyne, C.B.; Ferris, R.L.; Sarkar, S.N. Innate Immune Signaling through Differential RIPK1 Expression Promote Tumor Progression in Head and Neck Squamous Cell Carcinoma. Carcinogenesis 2016, 37, 522-529. [CrossRef]

152. Strilic, B.; Yang, L.; Albarrán-Juárez, J.; Wachsmuth, L.; Han, K.; Müller, U.C.; Pasparakis, M.; Offermanns, S. Tumour-Cell-Induced Endothelial Cell Necroptosis via Death Receptor 6 Promotes Metastasis. Nature 2016, 536, 215-218. [CrossRef]

153. Feng, X.; Song, Q.; Yu, A.; Tang, H.; Peng, Z.; Wang, X. Receptor-Interacting Protein Kinase 3 Is a Predictor of Survival and Plays a Tumor Suppressive Role in Colorectal Cancer. Neoplasma 2015, 62, 592-601. [CrossRef] [PubMed]

154. Höckendorf, U.; Yabal, M.; Herold, T.; Munkhbaatar, E.; Rott, S.; Jilg, S.; Kauschinger, J.; Magnani, G.; Reisinger, F.; Heuser, M.; et al. RIPK3 Restricts Myeloid Leukemogenesis by Promoting Cell Death and Differentiation of Leukemia Initiating Cells. Cancer Cell 2016, 30, 75-91. [CrossRef] [PubMed]

155. Fulda, S. Therapeutic Exploitation of Necroptosis for Cancer Therapy. Semin. Cell Dev. Biol. 2014, 35, 51-56. [CrossRef] [PubMed]

156. Sprooten, J.; De Wijngaert, P.; Vanmeerbeek, I.; Martin, S.; Vangheluwe, P.; Schlenner, S.; Krysko, D.V.; Parys, J.B.; Bultynck, G.; Vandenabeele, P.; et al. Necroptosis in Immuno-Oncology and Cancer Immunotherapy. Cells 2020, 9, 1823. [CrossRef] [PubMed]

157. Chefetz, I.; Grimley, E.; Yang, K.; Hong, L.; Vinogradova, E.V.; Suciu, R.; Kovalenko, I.; Karnak, D.; Morgan, C.A.; Chtcherbinine, M.; et al. A Pan-ALDH1A Inhibitor Induces Necroptosis in Ovarian Cancer Stem-like Cells. Cell Rep. 2019, 26, $3061-3075$. [CrossRef] [PubMed]

158. Parzych, K.R.; Klionsky, D.J. An Overview of Autophagy: Morphology, Mechanism, and Regulation. Antioxid. Redox Signal. 2014, 20, 460-473. [CrossRef]

159. Massey, A.; Kiffin, R.; Cuervo, A.M. Pathophysiology of Chaperone-Mediated Autophagy. Int. J. Biochem. Cell Biol. 2004, 36, 2420-2434. [CrossRef]

160. Mulcahy Levy, J.M.; Thorburn, A. Autophagy in Cancer: Moving from Understanding Mechanism to Improving Therapy Responses in Patients. Cell Death Differ. 2020, 27, 843-857. [CrossRef]

161. Towers, C.G.; Thorburn, A. Therapeutic Targeting of Autophagy. EBioMedicine 2016, 14, 15-23. [CrossRef]

162. Maes, H.; Rubio, N.; Garg, A.D.; Agostinis, P. Autophagy: Shaping the Tumor Microenvironment and Therapeutic Response. Trends Mol. Med. 2013, 19, 428-446. [CrossRef]

163. Jung, C.H.; Jun, C.B.; Ro, S.-H.; Kim, Y.-M.; Otto, N.M.; Cao, J.; Kundu, M.; Kim, D.-H. ULK-Atg13-FIP200 Complexes Mediate MTOR Signaling to the Autophagy Machinery. Mol. Biol. Cell 2009, 20, 1992-2003. [CrossRef] [PubMed]

164. Mercer, C.A.; Kaliappan, A.; Dennis, P.B. A Novel, Human Atg13 Binding Protein, Atg101, Interacts with ULK1 and Is Essential for Macroautophagy. Autophagy 2009, 5, 649-662. [CrossRef] [PubMed]

165. Yang, X.; Yu, D.-D.; Yan, F.; Jing, Y.-Y.; Han, Z.-P.; Sun, K.; Liang, L.; Hou, J.; Wei, L.-X. The Role of Autophagy Induced by Tumor Microenvironment in Different Cells and Stages of Cancer. Cell Biosci. 2015, 5, 14. [CrossRef] [PubMed]

166. Geng, J.; Klionsky, D.J. The Atg8 and Atg12 Ubiquitin-like Conjugation Systems in Macroautophagy. "Protein Modifications: Beyond the Usual Suspects" Review Series. EMBO Rep. 2008, 9, 859-864. [CrossRef] [PubMed]

167. Tanida, I.; Ueno, T.; Kominami, E. LC3 and Autophagy. Methods Mol. Biol. 2008, 445, 77-88. [CrossRef]

168. Nazio, F.; Bordi, M.; Cianfanelli, V.; Locatelli, F.; Cecconi, F. Autophagy and Cancer Stem Cells: Molecular Mechanisms and Therapeutic Applications. Cell Death Differ. 2019, 26, 690-702. [CrossRef] 
169. Gong, C.; Bauvy, C.; Tonelli, G.; Yue, W.; Deloménie, C.; Nicolas, V.; Zhu, Y.; Domergue, V.; Marin-Esteban, V.; Tharinger, H.; et al. Beclin 1 and Autophagy Are Required for the Tumorigenicity of Breast Cancer Stem-like/Progenitor Cells. Oncogene 2013, 32, 2261-2272. [CrossRef]

170. Chaterjee, M.; van Golen, K.L. Breast Cancer Stem Cells Survive Periods of Farnesyl-Transferase Inhibitor-Induced Dormancy by Undergoing Autophagy. Bone Marrow Res. 2011, 2011, 1-7. [CrossRef]

171. Song, Y.-J.; Zhang, S.-S.; Guo, X.-L.; Sun, K.; Han, Z.-P.; Li, R.; Zhao, Q.-D.; Deng, W.-J.; Xie, X.-Q.; Zhang, J.-W.; et al. Autophagy Contributes to the Survival of CD133+ Liver Cancer Stem Cells in the Hypoxic and Nutrient-Deprived Tumor Microenvironment. Cancer Lett. 2013, 339, 70-81. [CrossRef]

172. Defective Autophagy Leads to the Suppression of Stem-like Features of CD271 + Osteosarcoma Cells I Journal of Biomedical Science I Full Text. Available online: https:/ /jbiomedsci.biomedcentral.com/articles/10.1186/s12929-016-0297-5 (accessed on 30 December 2020).

173. Peng, Q.; Qin, J.; Zhang, Y.; Cheng, X.; Wang, X.; Lu, W.; Xie, X.; Zhang, S. Autophagy Maintains the Stemness of Ovarian Cancer Stem Cells by FOXA2. J. Exp. Clin. Cancer Res. 2017, 36, 171. [CrossRef]

174. Buccarelli, M.; Marconi, M.; Pacioni, S.; De Pascalis, I.; D’Alessandris, Q.G.; Martini, M.; Ascione, B.; Malorni, W.; Larocca, L.M.; Pallini, R.; et al. Inhibition of Autophagy Increases Susceptibility of Glioblastoma Stem Cells to Temozolomide by Igniting Ferroptosis. Cell Death Dis. 2018, 9, 1-17. [CrossRef] [PubMed]

175. Zhu, H.; Wang, D.; Liu, Y.; Su, Z.; Zhang, L.; Chen, F.; Zhou, Y.; Wu, Y.; Yu, M.; Zhang, Z.; et al. Role of the Hypoxia-Inducible Factor-1 Alpha Induced Autophagy in the Conversion of Non-Stem Pancreatic Cancer Cells into CD133+ Pancreatic Cancer Stem-like Cells. Cancer Cell Int. 2013, 13, 119. [CrossRef] [PubMed]

176. Wolf, J.; Dewi, D.L.; Fredebohm, J.; Müller-Decker, K.; Flechtenmacher, C.; Hoheisel, J.D.; Boettcher, M. A Mammosphere Formation RNAi Screen Reveals That ATG4A Promotes a Breast Cancer Stem-like Phenotype. Breast. Cancer Res. 2013, 15, R109. [CrossRef] [PubMed]

177. Yeo, S.K.; Wen, J.; Chen, S.; Guan, J.-L. Autophagy Differentially Regulates Distinct Breast Cancer Stem-like Cells in Murine Models via EGFR/Stat3 and Tgf $\beta /$ Smad Signaling. Cancer Res. 2016, 76, 3397-3410. [CrossRef] [PubMed]

178. Maycotte, P.; Jones, K.L.; Goodall, M.L.; Thorburn, J.; Thorburn, A. Autophagy Supports Breast Cancer Stem Cell Maintenance by Regulating IL6 Secretion. Mol. Cancer Res. 2015, 13, 651-658. [CrossRef] [PubMed]

179. Iliopoulos, D.; Hirsch, H.A.; Wang, G.; Struhl, K. Inducible Formation of Breast Cancer Stem Cells and Their Dynamic Equilibrium with Non-Stem Cancer Cells via IL6 Secretion. Proc. Natl. Acad. Sci. USA 2011, 108, 1397-1402. [CrossRef] [PubMed]

180. Farhan, M.; Silva, M.; Li, S.; Yan, F.; Fang, J.; Peng, T.; Hu, J.; Tsao, M.; Little, P.; Zheng, W. The Role of FOXOs and Autophagy in Cancer and Metastasis-Implications in Therapeutic Development. Med. Res. Rev. 2020, 40, 2089-2113. [CrossRef]

181. Jiramongkol, Y.; Lam, E.W.-F. FOXO Transcription Factor Family in Cancer and Metastasis. Cancer Metastasis Rev. 2020, 39, 681-709. [CrossRef]

182. Farhan, M.; Silva, M.; Xingan, X.; Huang, Y.; Zheng, W. Role of FOXO Transcription Factors in Cancer Metabolism and Angiogenesis. Cells 2020, 9, 1586. [CrossRef]

183. van Doeselaar, S.; Burgering, B.M.T.; van Doeselaar, S.; Burgering, B. FOXOs Maintaining the Equilibrium for Better or for Worse. Curr. Top. Dev. Biol. 2018, 127, 49-103.

184. Liang, R.; Ghaffari, S. Stem Cells Seen Through the FOXO Lens: An Evolving Paradigm. Curr. Top Dev. Biol. 2018, $127,23-47$. [CrossRef] [PubMed]

185. Prabhu, V.V.; Allen, J.E.; Dicker, D.T.; El-Deiry, W.S. Small-Molecule ONC201/TIC10 Targets Chemotherapy-Resistant Colorectal Cancer Stem-like Cells in an Akt/Foxo3a/TRAIL-Dependent Manner. Cancer Res. 2015, 75, 1423-1432. [CrossRef] [PubMed]

186. Smit, L.; Berns, K.; Spence, K.; Ryder, W.D.; Zeps, N.; Madiredjo, M.; Beijersbergen, R.; Bernards, R.; Clarke, R.B. An Integrated Genomic Approach Identifies That the PI3K/AKT/FOXO Pathway Is Involved in Breast Cancer Tumor Initiation. Oncotarget 2016, 7, 2596-2610. [CrossRef]

187. Sunayama, J.; Sato, A.; Matsuda, K.-I.; Tachibana, K.; Watanabe, E.; Seino, S.; Suzuki, K.; Narita, Y.; Shibui, S.; Sakurada, K.; et al. FoxO3a Functions as a Key Integrator of Cellular Signals That Control Glioblastoma Stem-like Cell Differentiation and Tumorigenicity. Stem Cells 2011, 29, 1327-1337. [CrossRef] [PubMed]

188. Ning, Y.; Luo, C.; Ren, K.; Quan, M.; Cao, J. FOXO3a-Mediated Suppression of the Self-Renewal Capacity of Sphere-Forming Cells Derived from the Ovarian Cancer SKOV3 Cell Line by 7-Difluoromethoxyl-5,4'-Di-n-Octyl Genistein. Mol. Med. Rep. 2014, 9, 1982-1988. [CrossRef]

189. Pellicano, F.; Scott, M.T.; Helgason, G.V.; Hopcroft, L.E.M.; Allan, E.K.; Aspinall-O’Dea, M.; Copland, M.; Pierce, A.; Huntly, B.J.P.; Whetton, A.D.; et al. The Antiproliferative Activity of Kinase Inhibitors in Chronic Myeloid Leukemia Cells Is Mediated by FOXO Transcription Factors. Stem Cells 2014, 32, 2324-2337. [CrossRef]

190. Naka, K.; Hoshii, T.; Muraguchi, T.; Tadokoro, Y.; Ooshio, T.; Kondo, Y.; Nakao, S.; Motoyama, N.; Hirao, A. TGF-Beta-FOXO Signalling Maintains Leukaemia-Initiating Cells in Chronic Myeloid Leukaemia. Nature 2010, 463, 676-680. [CrossRef]

191. Sharif, T.; Martell, E.; Dai, C.; Kennedy, B.E.; Murphy, P.; Clements, D.R.; Kim, Y.; Lee, P.W.K.; Gujar, S.A. Autophagic Homeostasis Is Required for the Pluripotency of Cancer Stem Cells. Autophagy 2017, 13, 264-284. [CrossRef]

192. Robert, T.; Vanoli, F.; Chiolo, I.; Shubassi, G.; Bernstein, K.A.; Rothstein, R.; Botrugno, O.A.; Parazzoli, D.; Oldani, A.; Minucci, S.; et al. HDACs Link the DNA Damage Response, Processing of Double-Strand Breaks and Autophagy. Nature 2011, 471, 74-79. [CrossRef] 
193. El Hout, M.; Cosialls, E.; Mehrpour, M.; Hamaï, A. Crosstalk between Autophagy and Metabolic Regulation of Cancer Stem Cells. Mol. Cancer 2020, 19, 27. [CrossRef]

194. Peixoto, J.; Lima, J. Metabolic Traits of Cancer Stem Cells. Dis. Model Mech. 2018, 11. [CrossRef] [PubMed]

195. Boya, P.; Codogno, P.; Rodriguez-Muela, N. Autophagy in Stem Cells: Repair, Remodelling and Metabolic Reprogramming. Development 2018, 145. [CrossRef] [PubMed]

196. Yuan, H.-D.; Quan, H.-Y.; Zhang, Y.; Kim, S.H.; Chung, S.-H. 20(S)-Ginsenoside Rg3-Induced Apoptosis in HT-29 Colon Cancer Cells Is Associated with AMPK Signaling Pathway. Mol. Med. Rep. 2010, 3, 825-831. [CrossRef]

197. Tang, Y.-C.; Zhang, Y.; Zhou, J.; Zhi, Q.; Wu, M.-Y.; Gong, F.-R.; Shen, M.; Liu, L.; Tao, M.; Shen, B.; et al. Ginsenoside Rg3 Targets Cancer Stem Cells and Tumor Angiogenesis to Inhibit Colorectal Cancer Progression in Vivo. Int. J. Oncol. 2018, 52, 127-138 [CrossRef] [PubMed]

198. Deng, S.; Wong, C.K.C.; Lai, H.-C.; Wong, A.S.T. Ginsenoside-Rb1 Targets Chemotherapy-Resistant Ovarian Cancer Stem Cells via Simultaneous Inhibition of Wnt/ $\beta$-Catenin Signaling and Epithelial-to-Mesenchymal Transition. Oncotarget 2017, 8, 25897-25914. [CrossRef]

199. Zhu, J.; Jiang, Y.; Yang, X.; Wang, S.; Xie, C.; Li, X.; Li, Y.; Chen, Y.; Wang, X.; Meng, Y.; et al. Wnt/ $\beta$-Catenin Pathway Mediates (-)-Epigallocatechin-3-Gallate (EGCG) Inhibition of Lung Cancer Stem Cells. Biochem. Biophys Res. Commun. 2017, 482, 15-21. [CrossRef]

200. Lee, S.H.; Nam, H.J.; Kang, H.J.; Kwon, H.W.; Lim, Y.C. Epigallocatechin-3-Gallate Attenuates Head and Neck Cancer Stem Cell Traits through Suppression of Notch Pathway. Eur. J. Cancer 2013, 49, 3210-3218. [CrossRef]

201. Fu, Y.; Chang, H.; Peng, X.; Bai, Q.; Yi, L.; Zhou, Y.; Zhu, J.; Mi, M. Resveratrol Inhibits Breast Cancer Stem-like Cells and Induces Autophagy via Suppressing Wnt/ $\beta$-Catenin Signaling Pathway. PLoS ONE 2014, 9, e102535. [CrossRef]

202. Cilibrasi, C.; Riva, G.; Romano, G.; Cadamuro, M.; Bazzoni, R.; Butta, V.; Paoletta, L.; Dalprà, L.; Strazzabosco, M.; Lavitrano, M.; et al. Resveratrol Impairs Glioma Stem Cells Proliferation and Motility by Modulating the Wnt Signaling Pathway. PLoS ONE 2017, 12, e0169854. [CrossRef]

203. Reddivari, L.; Charepalli, V.; Radhakrishnan, S.; Vadde, R.; Elias, R.J.; Lambert, J.D.; Vanamala, J.K.P. Grape Compounds Suppress Colon Cancer Stem Cells in Vitro and in a Rodent Model of Colon Carcinogenesis. BMC Complement Altern Med. 2016, 16, 278. [CrossRef]

204. Guo, M.; Wang, M.; Zhang, X.; Deng, H.; Wang, Z.-Y. Broussoflavonol B Restricts Growth of ER-Negative Breast Cancer Stem-like Cells. Anticancer. Res. 2013, 33, 1873-1879. [PubMed]

205. Wang, X.; Qiu, J.; Yang, G.; Altman, A.R.; Reisman, D.S.; Higginson, J.S.; Davis, I. The Radiosensitizing Effect of Curcumin on CD133+ Rectal Cancer Cells. Chin. J. Gen. Surg. 2013, 28, 134-137.

206. Zhou, Q.; Ye, M.; Lu, Y.; Zhang, H.; Chen, Q.; Huang, S.; Su, S. Curcumin Improves the Tumoricidal Effect of Mitomycin C by Suppressing ABCG2 Expression in Stem Cell-Like Breast Cancer Cells. PLoS ONE 2015, 10, e0136694. [CrossRef] [PubMed]

207. Wang, L.; Guo, H.; Yang, L.; Dong, L.; Lin, C.; Zhang, J.; Lin, P.; Wang, X. Morusin Inhibits Human Cervical Cancer Stem Cell Growth and Migration through Attenuation of NF-KB Activity and Apoptosis Induction. Mol. Cell Biochem. 2013, 379, 7-18. [CrossRef] [PubMed]

208. Guo, H.; Liu, C.; Yang, L.; Dong, L.; Wang, L.; Wang, Q.; Li, H.; Zhang, J.; Lin, P.; Wang, X. Morusin Inhibits Glioblastoma Stem Cell Growth in Vitro and in Vivo through Stemness Attenuation, Adipocyte Transdifferentiation, and Apoptosis Induction. Mol. Carcinog. 2016, 55, 77-89. [CrossRef] [PubMed]

209. Zhang, Q.; Li, X.-T.; Chen, Y.; Chen, J.-Q.; Zhu, J.-Y.; Meng, Y.; Wang, X.-Q.; Li, Y.; Geng, S.-S.; Xie, C.-F.; et al. Wnt/ $\beta-C a t e n i n$ Signaling Mediates the Suppressive Effects of Diallyl Trisulfide on Colorectal Cancer Stem Cells. Cancer Chemother. Pharmacol. 2018, 81, 969-977. [CrossRef] [PubMed]

210. Li, X.; Meng, Y.; Xie, C.; Zhu, J.; Wang, X.; Li, Y.; Geng, S.; Wu, J.; Zhong, C.; Li, M. Diallyl Trisulfide Inhibits Breast Cancer Stem Cells via Suppression of Wnt/ $\beta$-Catenin Pathway. J Cell Biochem. 2018, 119, 4134-4141. [CrossRef] [PubMed]

211. Gomez-Cabrero, A.; Wrasidlo, W.; Reisfeld, R.A. IMD-0354 Targets Breast Cancer Stem Cells: A Novel Approach for an Adjuvant to Chemotherapy to Prevent Multidrug Resistance in a Murine Model. PLoS ONE 2013, 8, e73607. [CrossRef]

212. Nanta, R.; Kumar, D.; Meeker, D.; Rodova, M.; Van Veldhuizen, P.J.; Shankar, S.; Srivastava, R.K. NVP-LDE-225 (Erismodegib) Inhibits Epithelial-Mesenchymal Transition and Human Prostate Cancer Stem Cell Growth in NOD/SCID IL2R $\gamma$ Null Mice by Regulating Bmi-1 and MicroRNA-128. Oncogenesis 2013, 2, e42. [CrossRef]

213. Alvero, A.B.; Montagna, M.K.; Holmberg, J.C.; Craveiro, V.; Brown, D.; Mor, G. Targeting the Mitochondria Activates Two Independent Cell Death Pathways in Ovarian Cancer Stem Cells. Mol. Cancer Ther. 2011, 10, 1385-1393. [CrossRef]

214. Chen, D.; Cui, Q.C.; Yang, H.; Dou, Q.P. Disulfiram, a Clinically Used Anti-Alcoholism Drug and Copper-Binding Agent, Induces Apoptotic Cell Death in Breast Cancer Cultures and Xenografts via Inhibition of the Proteasome Activity. Cancer Res. 2006, 66, 10425-10433. [CrossRef] [PubMed]

215. Wang, W.; McLeod, H.L.; Cassidy, J. Disulfiram-Mediated Inhibition of NF-KappaB Activity Enhances Cytotoxicity of 5Fluorouracil in Human Colorectal Cancer Cell Lines. Int. J. Cancer 2003, 104, 504-511. [CrossRef] [PubMed]

216. Jiao, Y.; Hannafon, B.N.; Ding, W.-Q. Disulfiram's Anticancer Activity: Evidence and Mechanisms. Anticancer. Agents Med. Chem. 2016, 16, 1378-1384. [CrossRef] [PubMed]

217. Ekinci, E.; Rohondia, S.; Khan, R.; Dou, Q.P. Repurposing Disulfiram as An Anti-Cancer Agent: Updated Review on Literature and Patents. Recent Pat. Anticancer. Drug Discov. 2019, 14, 113-132. [CrossRef] 
218. Yang, Z.; Guo, F.; Albers, A.E.; Sehouli, J.; Kaufmann, A.M. Disulfiram Modulates ROS Accumulation and Overcomes Synergistically Cisplatin Resistance in Breast Cancer Cell Lines. Biomed. Pharmacother. 2019, 113, 108727. [CrossRef]

219. Hothi, P.; Martins, T.J.; Chen, L.; Deleyrolle, L.; Yoon, J.-G.; Reynolds, B.; Foltz, G. High-Throughput Chemical Screens Identify Disulfiram as an Inhibitor of Human Glioblastoma Stem Cells. Oncotarget 2012, 3, 1124-1136. [CrossRef]

220. Zhang, C.C.; Yan, Z.; Zong, Q.; Fang, D.D.; Painter, C.; Zhang, Q.; Chen, E.; Lira, M.E.; John-Baptiste, A.; Christensen, J.G. Synergistic Effect of the $\gamma$-Secretase Inhibitor PF-03084014 and Docetaxel in Breast Cancer Models. Stem Cells Transl. Med. 2013, 2, 233-242. [CrossRef]

221. Galuppo, R.; Maynard, E.; Shah, M.; Daily, M.F.; Chen, C.; Spear, B.T.; Gedaly, R. Synergistic Inhibition of HCC and Liver Cancer Stem Cell Proliferation by Targeting RAS/RAF/MAPK and WNT/ $\beta$-Catenin Pathways. Anticancer. Res. 2014, 34, $1709-1713$.

222. Ashizawa, T.; Miyata, H.; Iizuka, A.; Komiyama, M.; Oshita, C.; Kume, A.; Nogami, M.; Yagoto, M.; Ito, I.; Oishi, T.; et al. Effect of the STAT3 Inhibitor STX-0119 on the Proliferation of Cancer Stem-like Cells Derived from Recurrent Glioblastoma. Int. J. Oncol. 2013, 43, 219-227. [CrossRef]

223. Wang, W.; Zheng, S.; He, H.; Ge, H.; Saeed, B. N,N-diethylaminobenzaldehyde Targets Aldehyde Dehydrogenase to Eradicate Human Pancreatic Cancer Cells. Exp. Ther. Med. 2020, 20, 662-670. [CrossRef]

224. Karsy, M.; Albert, L.; Tobias, M.E.; Murali, R.; Jhanwar-Uniyal, M. All-Trans Retinoic Acid Modulates Cancer Stem Cells of Glioblastoma Multiforme in an MAPK-Dependent Manner. Anticancer. Res. 2010, 30, 4915-4920. [PubMed]

225. Young, M.-J.; Wu, Y.-H.; Chiu, W.-T.; Weng, T.-Y.; Huang, Y.-F.; Chou, C.-Y. All-Trans Retinoic Acid Downregulates ALDH1Mediated Stemness and Inhibits Tumour Formation in Ovarian Cancer Cells. Carcinogenesis 2015, 36, 498-507. [CrossRef] [PubMed]

226. Balic, A.; Sørensen, M.D.; Trabulo, S.M.; Sainz, B.; Cioffi, M.; Vieira, C.R.; Miranda-Lorenzo, I.; Hidalgo, M.; Kleeff, J.; Erkan, M.; et al. Chloroquine Targets Pancreatic Cancer Stem Cells via Inhibition of CXCR4 and Hedgehog Signaling. Mol. Cancer Ther. 2014, 13, 1758-1771. [CrossRef]

227. Kreso, A.; van Galen, P.; Pedley, N.M.; Lima-Fernandes, E.; Frelin, C.; Davis, T.; Cao, L.; Baiazitov, R.; Du, W.; Sydorenko, N.; et al. Self-Renewal as a Therapeutic Target in Human Colorectal Cancer. Nat. Med. 2014, 20, 29-36. [CrossRef]

228. Flamme, M.; Cressey, P.B.; Lu, C.; Bruno, P.M.; Eskandari, A.; Hemann, M.T.; Hogarth, G.; Suntharalingam, K. Induction of Necroptosis in Cancer Stem Cells Using a Nickel(II)-Dithiocarbamate Phenanthroline Complex. Chem. A Eur. J. 2017, 23, 9674-9682. [CrossRef] [PubMed]

229. Novohradsky, V.; Markova, L.; Kostrhunova, H.; Trávníček, Z.; Brabec, V.; Kasparkova, J. An Anticancer Os(II) Bathophenanthroline Complex as a Human Breast Cancer Stem Cell-Selective, Mammosphere Potent Agent That Kills Cells by Necroptosis. Sci. Rep. 2019, 9. [CrossRef]

230. Calvani, M.; Pasha, A.; Favre, C. Nutraceutical Boom in Cancer: Inside the Labyrinth of Reactive Oxygen Species. Int. J. Mol. Sci. 2020, 21, 1936. [CrossRef]

231. Lin, S.-R.; Chang, C.-H.; Hsu, C.-F.; Tsai, M.-J.; Cheng, H.; Leong, M.K.; Sung, P.-J.; Chen, J.-C.; Weng, C.-F. Natural Compounds as Potential Adjuvants to Cancer Therapy: Preclinical Evidence. Br. J. Pharmacol. 2020, 177, 1409-1423. [CrossRef]

232. Majolo, F.; de Oliveira Becker Delwing, L.K.; Marmitt, D.J.; Bustamante-Filho, I.C.; Goettert, M.I. Medicinal Plants and Bioactive Natural Compounds for Cancer Treatment: Important Advances for Drug Discovery. Phytochem. Lett. 2019, 31, $196-207$. [CrossRef]

233. Benot-Dominguez, R.; Tupone, M.G.; Castelli, V.; d'Angelo, M.; Benedetti, E.; Quintiliani, M.; Cinque, B.; Forte, I.M.; Cifone, M.G.; Ippoliti, R.; et al. Olive Leaf Extract Impairs Mitochondria by Pro-Oxidant Activity in MDA-MB-231 and OVCAR-3 Cancer Cells. Biomed. Pharmacother. 2020, 134, 111139. [CrossRef]

234. Montales, M.T.E.; Rahal, O.M.; Kang, J.; Rogers, T.J.; Prior, R.L.; Wu, X.; Simmen, R.C.M. Repression of Mammosphere Formation of Human Breast Cancer Cells by Soy Isoflavone Genistein and Blueberry Polyphenolic Acids Suggests Diet-Mediated Targeting of Cancer Stem-like/Progenitor Cells. Carcinogenesis 2012, 33, 652-660. [CrossRef] [PubMed]

235. Montales, M.T.E.; Rahal, O.M.; Nakatani, H.; Matsuda, T.; Simmen, R.C.M. Repression of Mammary Adipogenesis by Genistein Limits Mammosphere Formation of Human MCF-7 Cells. J. Endocrinol. 2013, 218, 135-149. [CrossRef] [PubMed]

236. Castelli, V.; Grassi, D.; Bocale, R.; d'Angelo, M.; Antonosante, A.; Cimini, A.; Ferri, C.; Desideri, G. Diet and Brain Health: Which Role for Polyphenols? Curr. Pharm. Des. 2018, 24, 227-238. [CrossRef] [PubMed]

237. Muralikrishnan, V.; Hurley, T.D.; Nephew, K.P. Targeting Aldehyde Dehydrogenases to Eliminate Cancer Stem Cells in Gynecologic Malignancies. Cancers 2020, 12, 961. [CrossRef] [PubMed]

238. Jin, N.; Zhu, X.; Cheng, F.; Zhang, L. Disulfiram/Copper Targets Stem Cell-like ALDH+ Population of Multiple Myeloma by Inhibition of ALDH1A1 and Hedgehog Pathway. J. Cell Biochem. 2018, 119, 6882-6893. [CrossRef]

239. Rezk, Y.A.; Yang, K.; Bai, S.; Mclean, K.; Johnston, C.; Reynolds, R.K.; Buckanovich, R.J. Disulfiram's Antineoplastic Effects on Ovarian Cancer. J. Cancer Ther. 2015, 6, 1196-1205. [CrossRef]

240. Guo, F.; Yang, Z.; Kulbe, H.; Albers, A.E.; Sehouli, J.; Kaufmann, A.M. Inhibitory Effect on Ovarian Cancer ALDH+ Stem-like Cells by Disulfiram and Copper Treatment through ALDH and ROS Modulation. Biomed. Pharmacother. 2019, 118, 109371. [CrossRef]

241. Liu, X.; Wang, L.; Cui, W.; Yuan, X.; Lin, L.; Cao, Q.; Wang, N.; Li, Y.; Guo, W.; Zhang, X.; et al. Targeting ALDH1A1 by Disulfiram/Copper Complex Inhibits Non-Small Cell Lung Cancer Recurrence Driven by ALDH-Positive Cancer Stem Cells. Oncotarget 2016, 7, 58516-58530. [CrossRef] 
242. Liu, P.; Brown, S.; Goktug, T.; Channathodiyil, P.; Kannappan, V.; Hugnot, J.-P.; Guichet, P.-O.; Bian, X.; Armesilla, A.L.; Darling, J.L.; et al. Cytotoxic Effect of Disulfiram/Copper on Human Glioblastoma Cell Lines and ALDH-Positive Cancer-Stem-like Cells. Br. J. Cancer 2012, 107, 1488-1497. [CrossRef]

243. Yip, N.C.; Fombon, I.S.; Liu, P.; Brown, S.; Kannappan, V.; Armesilla, A.L.; Xu, B.; Cassidy, J.; Darling, J.L.; Wang, W. Disulfiram Modulated ROS-MAPK and NFкB Pathways and Targeted Breast Cancer Cells with Cancer Stem Cell-like Properties. Br. J. Cancer 2011, 104, 1564-1574. [CrossRef]

244. Liu, P.; Kumar, I.S.; Brown, S.; Kannappan, V.; Tawari, P.E.; Tang, J.Z.; Jiang, W.; Armesilla, A.L.; Darling, J.L.; Wang, W. Disulfiram Targets Cancer Stem-like Cells and Reverses Resistance and Cross-Resistance in Acquired Paclitaxel-Resistant Triple-Negative Breast Cancer Cells. Br. J. Cancer 2013, 109, 1876-1885. [CrossRef] [PubMed]

245. Januchowski, R.; Wojtowicz, K.; Sterzyfska, K.; Sosifska, P.; Andrzejewska, M.; Zawierucha, P.; Nowicki, M.; Zabel, M. Inhibition of ALDH1A1 Activity Decreases Expression of Drug Transporters and Reduces Chemotherapy Resistance in Ovarian Cancer Cell Lines. Int. J. Biochem. Cell Biol. 2016, 78, 248-259. [CrossRef] [PubMed]

246. Lee, M.-R.; Ji, S.-Y.; Mia-Jan, K.; Cho, M.-Y. Chemoresistance of CD133(+) Colon Cancer May Be Related with Increased Survivin Expression. Biochem. Biophys Res. Commun. 2015, 463, 229-234. [CrossRef] [PubMed]

247. All-Trans Retinoic Acid Suppresses Malignant Characteristics of CD133-Positive Thyroid Cancer Stem Cells and Induces Apoptosis-PubMed. Available online: https:/ / pubmed.ncbi.nlm.nih.gov/28817605/ (accessed on 30 December 2020).

248. All-Trans Retinoic Acid Reduces Cancer Stem Cell-like Cell-Mediated Resistance to Gefitinib in NSCLC Adenocarcinoma Cells. Available online: https:/ /www.ncbi.nlm.nih.gov/pmc/articles/PMC7161137/ (accessed on 30 December 2020).

249. Hirsch, H.A.; Iliopoulos, D.; Tsichlis, P.N.; Struhl, K. Metformin Selectively Targets Cancer Stem Cells, and Acts Together with Chemotherapy to Block Tumor Growth and Prolong Remission. Cancer Res. 2009, 69, 7507-7511. [CrossRef] [PubMed]

250. Gupta, P.B.; Onder, T.T.; Jiang, G.; Tao, K.; Kuperwasser, C.; Weinberg, R.A.; Lander, E.S. Identification of Selective Inhibitors of Cancer Stem Cells by High-Throughput Screening. Cell 2009, 138, 645-659. [CrossRef]

251. Vidal, S.J.; Rodriguez-Bravo, V.; Galsky, M.; Cordon-Cardo, C.; Domingo-Domenech, J. Targeting Cancer Stem Cells to Suppress Acquired Chemotherapy Resistance. Oncogene 2014, 33, 4451-4463. [CrossRef] 